\title{
Influence of an Antarctic waste dump on recruitment to nearshore marine soft-sediment assemblages
}

\author{
Jonathan S. Stark ${ }^{1, *}$, Martin J. Riddle ${ }^{1}$, Stephen D. A. Smith ${ }^{2,3}$ \\ ${ }^{1}$ Australian Antarctic Division, Department of the Environment and Heritage, Channel Highway, Kingston, \\ 7050 Tasmania, Australia \\ ${ }^{2}$ School of Environmental Sciences and Natural Resource Management, University of New England, Armidale, \\ 2351 New South Wales, Australia \\ ${ }^{3}$ National Marine Science Centre, Bay Drive, Charlesworth Bay, Coffs Harbour, 2450 New South Wales, Australia
}

\begin{abstract}
Abandoned waste dumps in Antarctica pose an environmental hazard due to contaminant mobilisation in marine and terrestrial habitats. At Casey Station, east Antarctica, a shoreline waste dump has contaminated adjacent marine sediments with metals, hydrocarbons and organic carbon. This study experimentally assessed a model whereby contamination of marine sediment can lead to changes in recruitment and differences in soft-sediment assemblages. We tested the hypotheses that recruitment would be different at disturbed 'station' locations compared to controls and different in contaminated sediment compared to control sediment. We conducted 2 reciprocal sedimenttransplant field experiments over 2 consecutive years in which defaunated sediments were deployed at disturbed locations and control locations and were recovered after 9 mo (March to November: winter), and also after 12 mo. The majority of fauna recruiting to the experiment were highly motile species with non-pelagic lecithotrophic larvae, such as gammarids, tanaids, isopods and gastropods. There were large differences in recruiting assemblages between all locations and there were significant differences in recruitment between disturbed and control locations. Assemblages in contaminated sediment were significantly different from those in control sediment. Differences in abundances of individual taxa between control and contaminated sediment were complex and difficult to interpret. Assemblages recruiting to the control locations were more variable than those recruiting to disturbed locations. This study provides evidence that contaminants in marine sediments adjacent to the waste dump at Casey Station may be having an environmental impact.
\end{abstract}

KEY WORDS: Environmental impact · Waste dump $\cdot$ Pollution $\cdot$ Soft-sediment macrofauna $\cdot$ Recruitment $\cdot$ Antarctica

Resale or republication not permitted without written consent of the publisher

\section{INTRODUCTION}

The problem of waste disposal at Antarctic research stations was historically dealt with by dumping rubbish into convenient terrestrial or marine locations adjacent to station facilities. Since the advent of the Protocol on Environmental Protection to the Antarctic Treaty in 1991 this practice has changed and in most cases waste is now returned to its country of origin. Most established Antarctic stations, however, have abandoned waste dumps of varying sizes containing a large variety of materials (e.g. Snape et al. 1998a), including metals and hydrocarbons (Snape et al. 2001). The migration of these contaminants off dump sites, principally by melt water entrainment and tidal inundation (Snape et al. 2001), has potential for environmental impact. For example, at the Australian base, Casey Station, in east Antarctica, metals and hydrocarbons have accumulated in marine sediments in Brown Bay, adjacent to an abandoned dump site (Snape et al. 2001, Stark et al. 2003b). Soft-sediment assemblages in Brown Bay are different from those in nearby control 
areas (Stark 2000, Stark et al. 2003c) and there are correlations between high concentrations of metals and lower diversity and dominance of opportunistic type species (Stark et al. 2003b). Experimental evidence is required, however, to demonstrate that the presence of contamination in sediments causes the observed differences in soft-sediment assemblages at Brown Bay.

Field experiments that examine the recruitment or recolonisation of benthic assemblages are a useful tool for the study of environmental impacts (Watzin \& Roscigno 1997, Glasby \& Underwood 1998, Olsgard 1999). Recruitment is defined here in the sense of Renaud et al. (1999) to incorporate settlement of larvae, post-settlement events and immigration of juveniles and adults from surrounding habitats over the period of study. Marine environmental impacts may be first manifest as changes in recruitment, which also constitutes the only path by which many populations could recover (Fairweather 1991). Recruitment is an important structuring factor in hard-bottom benthic communities (Underwood \& Denley 1984, Caley et al. 1996, Hunt \& Scheibling 1997), but its role in structuring soft-bottom communities is less clear and has been shown to have a wide variety of influences (review by Olafsson et al. 1994).

Pollution has the potential to create significant impacts in benthic assemblages during recruitment of fauna, particularly in sediments where contaminants accumulate (Bonsdorff et al. 1990, Olsgard 1999). Settling larvae have been found to be sensitive to chemicals and toxins (Dubilier 1988), to display selective preferences for particular substrates (Woodin 1986, Butman 1987, Butman \& Grassle 1992) and to discriminate between settlement sites on the basis of presence of other fauna, grain size, organic matter and chemical cues (Gray 1974, Ambrose 1984a,b, Woodin 1986, Dubilier 1988). Early life history stages, during settling and metamorphosis of invertebrate larvae, are the most critical in development (Obreski 1979, Watzin \& Roscigno 1997, Olsgard 1999). Pollution of sediments may change settlement cues, resulting in avoidance by larvae or early mortality of recruits (Menzie 1984). Juvenile and adult recruits have also been shown to selectively discriminate between contaminated and control sediments in manipulative experiments (Lenihan et al. 1995).

Studies of environmental impacts in soft sediments are usually confined to sampling existing (i.e. already established) assemblages (e.g. Cross \& Thomson 1987, Hyland et al. 1994). Existing assemblages may have been affected by past, short-term (pulse) disturbances or may continue to be affected by ongoing, long-term (press) disturbances (sensu Glasby \& Underwood 1996). The establishment of new assemblages, however, is only affected by ongoing disturbances (Glasby \&
Underwood 1996). Methods are necessary that can distinguish the history of a location (i.e. past disturbances) from the comparison of locations under present conditions (Glasby \& Underwood 1996). Recruitment experiments can be used to determine if a disturbance is having an ongoing effect. Ongoing disturbances, such as a sewage outfall, are likely to have a press effect, but a disturbance such as the dumping of rubbish on an Antarctic shoreline may either cause a short-term pulse effect or if contamination is persistent, may have an ongoing press effect.

Based on the premise that differences in soft-sediment assemblages at Casey between potentially disturbed locations (the waste tip and the sewage outfall, hereafter referred to as 'station' locations) and control locations are being caused by contamination of sediment by anthropogenic pollutants, the aims of this study were to test the hypotheses that (1) recruitment is different between locations, (2) recruiting assemblages at station locations are generally different from those at control locations, (3) recruiting assemblages are different between contaminated sediment and control sediment, and (4) there are differences in variability of recruitment between control and station locations, and between control and contaminated sediments.

\section{MATERIALS AND METHODS}

Study locations and experimental design. Casey Station is situated in the Windmill Islands in East Antarctica at $66^{\circ} 17^{\prime} \mathrm{S}, 110^{\circ} 32^{\prime} \mathrm{E}$ (Fig. 1). The shallow $(<35 \mathrm{~m})$ marine benthic environment consists of poorly sorted glacial till overlying bedrock, and is a mosaic of muddy/sand, gravel, cobbles and boulders. The benthic terrain is very uneven, with many small shelves and benches and small basins, and large areas of homogenous flat seabed are rare in nearshore areas. The experiments were conducted in Brown Bay, O'Brien Bay and Shannon Bay (Fig. 1).

Brown Bay: Rubbish was dumped along the shoreline of and into Brown Bay for over $21 \mathrm{yr}$ and was discontinued in 1986 (Deprez et al. 1999). During the annual summer thaw, a melt stream runs through the dump site and into Brown Bay, entraining contaminated particulates and dissolved material from the dump. Brown Bay sediment is contaminated by heavy metals and hydrocarbons from the abandoned garbage dump (Snape et al. 1998b, 2001, Scouller et al. 2000).

O'Brien Bay: Two undisturbed control locations were situated in O'Brien Bay (Locations 4 and 5 in Fig. 1). The sediment is uncontaminated and many metals found at Brown Bay are below detection limits at O'Brien Bay (Snape et al. 2001, Stark et al. 2003b). 
Shannon Bay: A second station location was also used, situated in front of the Casey Station sewage outfall in Shannon Bay (Location 1 in Fig. 1). Sediments in the bay are contaminated, but to a lesser extent than in Brown Bay (Stark et al. 2003b).

Expt 1, March to November 1997: Sediments were deployed at 2 locations, Brown Bay and O'Brien Bay (Fig. 1). Within each location 2 trays of each sediment type (contaminated and control) were placed at each of 2 depths (shallow: $\sim 15 \mathrm{~m}$; deep: $\sim 25 \mathrm{~m}$ ), with 6 replicate pots per tray. The 2 depths at each location were separated by up to several hundred metres, potentially confounding effects of depth with spatial variation. Effects of depth at Brown Bay may be further confounded by the proximity of the shallow site to the waste dump $(\sim 100 \mathrm{~m})$, while the deep site was $\sim 300 \mathrm{~m}$ away. For statistical analyses, each combination of location and depth was treated separately (termed 'site'), and any depth effects were interpreted with caution. At each site the 4 trays were haphazardly placed by boat in an area $\sim 20 \mathrm{~m}$ in diameter. The trays were left in place from March to November 1997, during which time the sea surface remained frozen; 1 tray of control sediment and 1 of contaminated sediment were lost from the O'Brien Bay-shallow site due to icebergs.

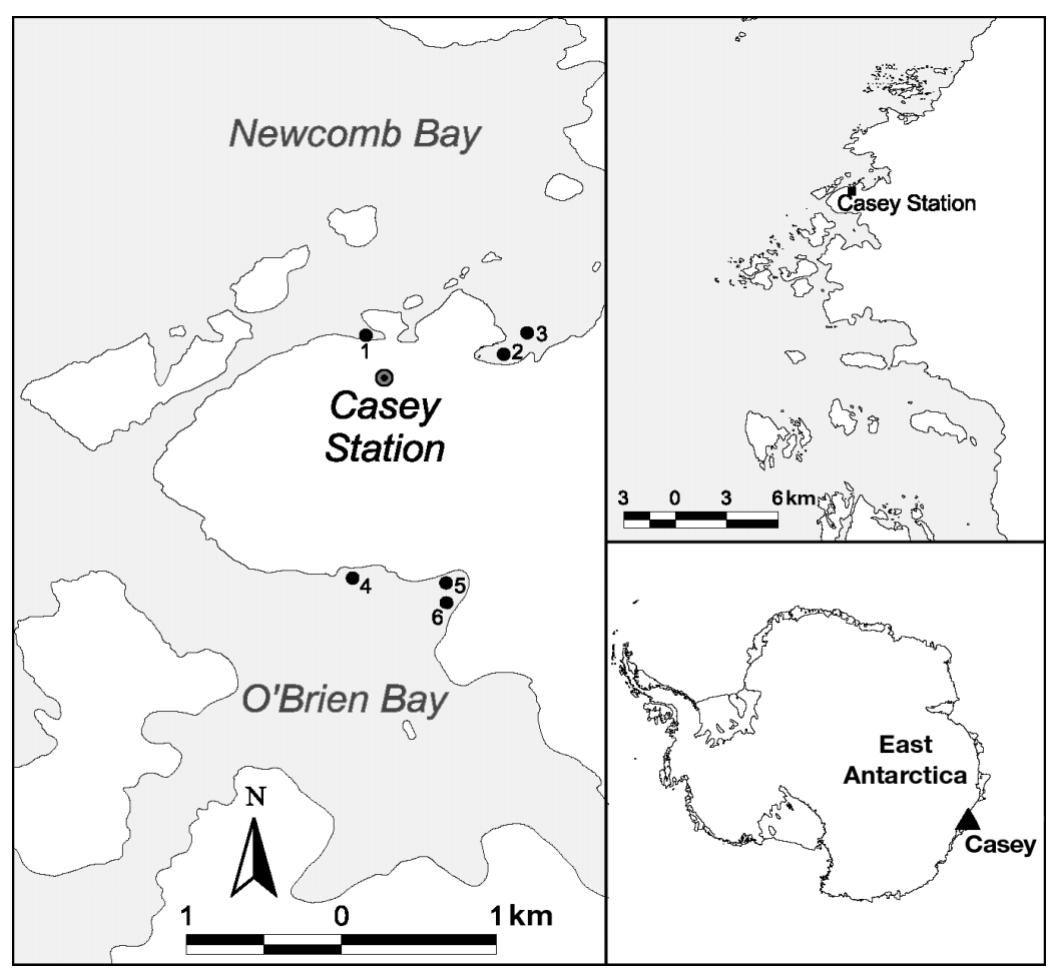

Fig. 1. Location of Casey Station and positions of experiments. 1: Shannon Bay (Expt 2); 2: Brown Bay shallow (Expt 1) and Brown Bay (Expt 2); 3: Brown Bay deep (Expt 1); 4: O'Brien Bay-3 (Expt 2); 5: O'Brien Bay shallow (Expt 1) and O'Brien Bay-2 (Expt 2); 6: O'Brien Bay deep (Expt 1)
Expt 2, March to November 1998 and to February 1999: Expt 1 had indicated possible effects of depth, so the second experiment was confined to $12-15 \mathrm{~m}$ depth. Experimental units were deployed in February/March 1998 at 4 locations, 2 control locations (O'Brien Bay-2 and O'Brien Bay-3) and 2 station locations (Shannon Bay and Brown Bay) (Fig. 1). There were 2 sampling times, at approximately 9 and 12 mo after deployment. At each location there were 4 trays of control sediment and 4 trays of contaminated sediment. Each tray was approximately 3 to $5 \mathrm{~m}$ apart. We retrieved 2 trays of each sediment type in late November/early December 1998; the remaining 2 trays of each treatment were retrieved in February 1999 and, at this time, 1 control tray was missing from Brown Bay and both control trays were missing from O'Brien Bay-3.

Defaunated sediments and experimental units: Sediment was collected from O'Brien Bay (control, uncontaminated sediment) and from Brown Bay (contaminated sediment) by van Veen grab and by divers using polyethylene buckets. Sediment was defaunated by freezing at $-20^{\circ} \mathrm{C}$ for a minimum of $48 \mathrm{~h}$, defrosting to room temperature and sieving through a $500 \mu \mathrm{m}$-mesh screen with seawater taken from the same sites. Material $>500 \mu \mathrm{m}$ was discarded to reduce effects of grain size differences between the 2 sediment types. The sediment was left to settle and overlying water was siphoned off, then homogenised and placed in plastic flowerpots, $12 \mathrm{~cm}$ diameter and $12 \mathrm{~cm}$ deep. Each pot had three $8 \times 8 \mathrm{~cm}$ holes cut into the sides and a $9 \mathrm{~cm}$ diameter hole in the bottom, covered by $300 \mu \mathrm{m}$ mesh, to prevent hypoxic conditions in the sediment. Each experimental unit consisted of a plastic tray $(60 \times 35 \times 10 \mathrm{~cm})$ containing 6 pots attached with plastic cable ties. Each tray had a rope bridle to allow lowering and raising, and a retrieval rope with a subsurface buoy $\sim 3$ to $4 \mathrm{~m}$ below the surface to prevent freezing into the sea ice. The units were gently lowered to the bottom from boats, and on retrieval were gently raised to the surface by divers. Pots were not covered or sealed on retrieval, and minor quantities of surface sediments may have been lost, but this was considered an equal effect among all treatments.

When retrieved, 4 samples from each tray were sieved through a $500 \mu \mathrm{m}$-mesh and fixed in $7 \%$ formalin 
with Biebrich scarlet stain; 2 samples from each tray were frozen for analysis of total organic carbon (TOC) and metals. Samples were sorted under a dissecting microscope and preserved in $70 \%$ ethanol. Fauna were identified to the highest and most convenient taxonomic resolution possible. Polychaetes were identified to family, crustaceans, bivalves and gastropods were generally identified to species. Echinoderms were identified to order, excepting the burrowing heart urchin of the genus Abatus. Other fauna included nemerteans, sipunculids, priapulids, oligochaetes and nematodes.

Statistical analyses. Tests of the multivariate null hypotheses of no differences among a priori defined groups were done using non-parametric multivariate analysis of variance (NP-MANOVA, Anderson 2000, 2001, McArdle \& Anderson 2001) and generalised discriminant analysis using the method CAP (canonical analysis of principal coordinates; Anderson 2002, Anderson \& Robinson 2003, Anderson \& Willis 2003). The F-ratio constructed in NP-MANOVA is analogous to Fisher's F-ratio and is constructed from sums of squared distances (in this case Bray-Curtis dissimilarities calculated from 4th-root-transformed species abundances) within and between groups (Anderson 2001). CAP has the advantage over NP-MANOVA of taking into account the correlation structure among variables (species), and provides a constrained ordination that maximises the differences among a priori groups (Anderson \& Willis 2003). NP-MANOVA was done using a 2-factor orthogonal design with permutation of residuals under a reduced model (Anderson 2000, 2001). Constrained CAP ordinations were also compared to unconstrained non-metric multidimension scaling (NMDS) ordinations. In addition ANOSIM was used to test for differences among unbalanced a priori defined groups using the PRIMER software package (Plymouth Marine Laboratory, UK). Similarity matrixes were calculated using the Bray-Curtis similarity measure on 4th-root-transformed abundances. Assemblage variability among groups was determined using the index of multivariate dispersion (IMD), which contrasts the average rank of similarities among one group (e.g. contaminated) to the average rank of similarities among another group (e.g. control) (Clarke \& Warwick 1994). IMD is constrained to range from -1 to +1 , and the endpoints of this range indicate that variation among samples from one group is greater than variation among samples from the other group. Taxa responsible for differences between groups were determined using similarity of percentages analysis (SIMPER; Clarke 1993).

Univariate analyses were done using analyses of variance (ANOVA) on abundances of taxa identified as being important contributors to differences between groups (using SIMPER), and also on diversity indices. Data from Expt 1 were analysed by a 4 -factor design with location, sediment type and depth as fixed, orthogonal factors and the 4 th factor, tray, nested in the other 3 factors ( $\mathrm{n}=4$ replicate pots per tray). Additionally, a 2-factor ANOVA was done with location and sediment type (as fixed, orthogonal factors) on the total number of taxa in each tray (pooling replicate pots within trays and using $n=4$ trays of each sediment type at each location as replicates). Data from Expt 2 were analysed by a 4 -factor design with 3 orthogonal factors: time, location, sediment type and the 4 th factor, tray, were nested in the above 3 factors $(n=4$ replicate pots per tray). Cochran's $C$-test was used to test for homogeneity of variances. If variances were heterogeneous, data were transformed (Snedecor \& Cochran 1980, Underwood 1981). Where heterogeneity of variances could not be removed by transformation and were significant at $p=0.05$, a lower probability level of $p=0.01$ was used. Multiple comparisons among means were done using a Student-Newman-Keuls (SNK) test. The Shannon-Wiener diversity $\left(H^{\prime}\right)$, species richness (Margalef's $d$ ) and evenness (Pielou's $J^{\prime}$ ) were calculated using natural logarithms (Base e). Several trays of sediment were lost during the experiments (due to icebergs and sea ice), and to compensate, the number of degrees of freedom of the residual was reduced in the ANOVAs and the averages of other appropriate treatments were substituted to balance the analyses (Underwood 1981, 1997).

To compare variability among treatments in Expt 1 the slope of the relationship between log (variance +1$)$ and $\log ($ mean +1$)$ (Warwick \& Clarke 1993) was examined using the abundance of each taxon averaged over the 8 replicate pots in the 2 trays in each treatment. This measure therefore includes variability at 2 spatial scales, within trays and between trays.

Geochemical analysis of samples. Samples for geochemical analysis were frozen, stored and transported to Australia at $-20^{\circ} \mathrm{C}$. Sediments for heavy-metal analysis were thawed for $12 \mathrm{~h}$ then oven-dried for $48 \mathrm{~h}$ at $60^{\circ} \mathrm{C}$. Metals were extracted from $5 \mathrm{~g}$ of whole sediment using $50 \mathrm{ml} 1 \mathrm{M} \mathrm{HCl}$, stirring continuously for $30 \mathrm{~min}$ at $\sim 25^{\circ} \mathrm{C}$. The extractant was filtered through a 0.45 um CN filter and analysed by inductively coupled plasma-mass spectrometry (ICP-MS) for copper, lead, zinc, cadmium, manganese, nickel, arsenic, chromium, iron and antimony. Sediments for total organic carbon (TOC) analysis were oven-dried, concentrated $\mathrm{HCl}$ was added to each sample to remove inorganic carbon, and $50 \mathrm{mg}$ per sample of sediment was analysed by a Dohrmann 190 combustion infrared total organic carbon analyser using Method USEPA9060. Each sample was analysed 2 to 3 times and averaged to obtain the final measurement. 


\section{RESULTS}

\section{Sediments}

Concentrations of copper, lead, zinc, silver and TOC were significantly greater in the contaminated sediment from Brown Bay than the control sediment from O'Brien Bay in pre-deployment sediments and after 9 mo in both experiments (Fig. 2) Concentrations of arsenic were slightly higher in contaminated sediment, and differences between treatments for cadmium were variable (Fig. 2). The highest concentrations of metals were in the contaminated sediments retrieved from Brown Bay, indicating further input of metals to those sediments (Fig. 2). The physical properties of the sediments from the 2 locations are similar: Brown Bay sediments have been classified as coarse-skewed, mediumto-coarse silts, and those from O'Brien Bay as coarseskewed, coarse silts to very fine sands (Stark et al. 2003b).

\section{Assemblage composition}

A total of 61 taxa had recruited to sediments in Expt 1 and 83 taxa in Expt 2 by 12 mo (75 by 9 mo). The comparative densities of the major taxonomic groups, averaged over each treatment, are shown in Fig. 3.
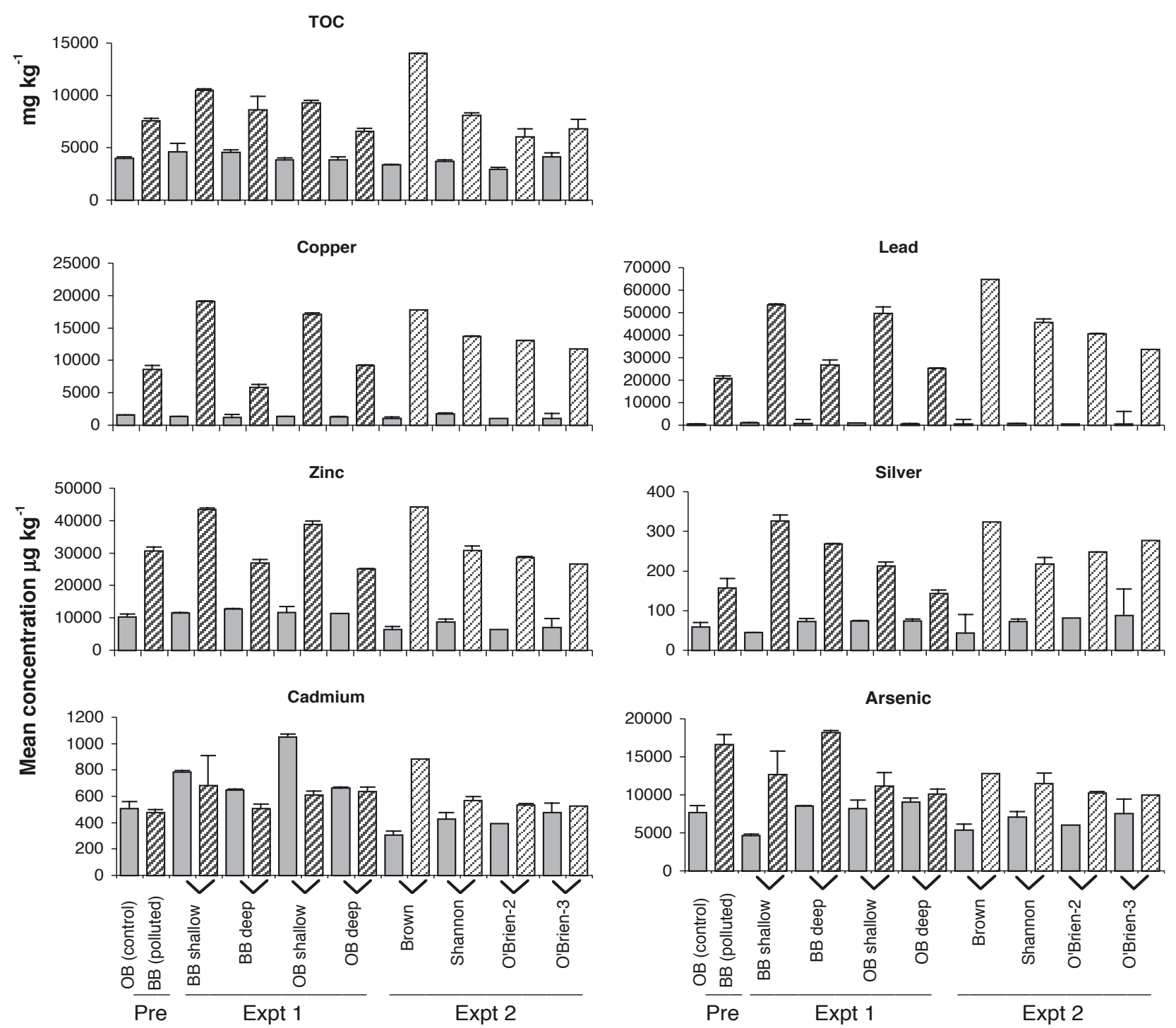

Fig. 2. Expts 1 and 2. Average concentration of total organic carbon (TOC) and heavy metals in each treatment at end of Expt 1 and at 9 mo in Expt 2, $\mathrm{n}=2$. Shaded bars: control sediments; hatched bars: contaminated sediments; OB: O'Brien Bay, BB: Brown Bay; Pre: concentrations in pre-deployment sediments 
Expt 1

a) $9 \mathrm{mo}$

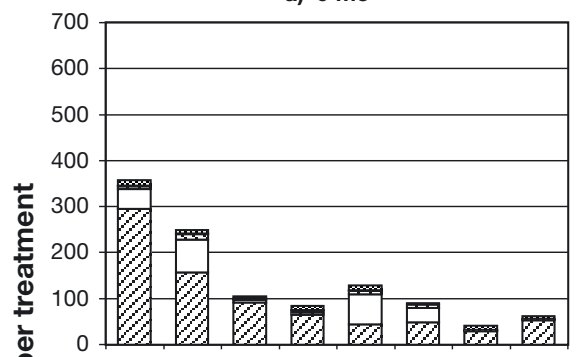

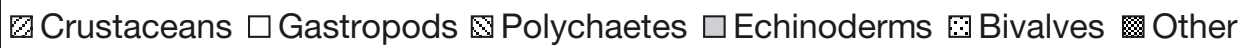

Expt 2 b) $9 \mathrm{mo}$

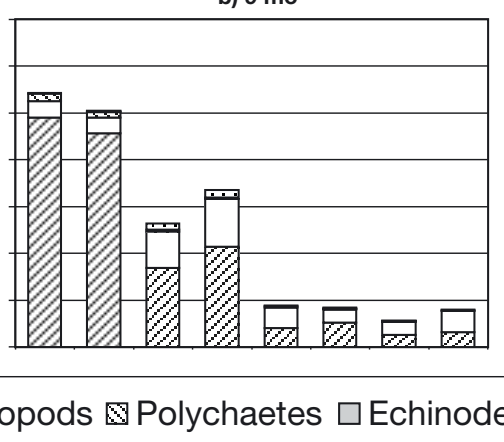

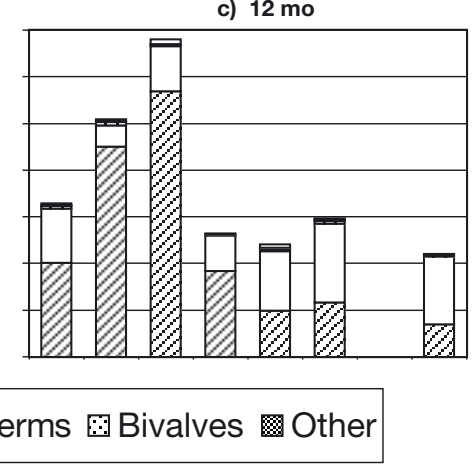

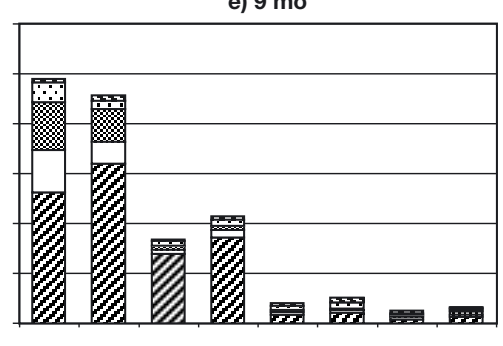

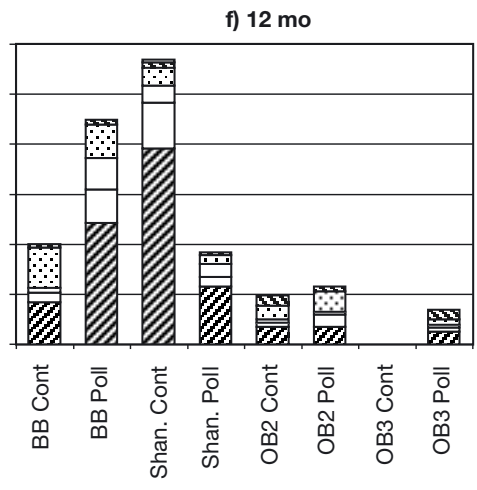

Gammarids $\square$ Tanaids Ostracods lsopods $\mathbf{\$}$ Copepods $\square$ Cumaceans

Fig. 3. Expts 1 and 2. (a-c) Average proportions of major taxa in each treatment. Other: nemerteans, nematodes, oligochaetes. $(d-f)$ Average proportion of major crustacean taxa in each treatment at each location. BB: Brown Bay; OB: O'Brien Bay; Shan: Shannon Bay; Shall: shallow; Cont: control; Poll: polluted

Crustaceans comprised the majority of fauna in both experiments. In Expt 2 gastropods comprised a larger proportion than in Expt 1, particularly by 12 mo, when there was a general decrease in the dominance of crustaceans and an increase in the proportion of gastropods (Fig. 3). The greatest temporal change was in the control sediment at Brown Bay, where crustaceans decreased from 90 to $60 \%$ of the total, but the fauna in the contaminated sediment changed very little (Fig. 3b,c). Control sediment at Shannon Bay also displayed greater temporal change than contaminated sediment. Crustaceans were more dominant at the station locations than control locations. Gastropods comprised a greater proportion of recruitment in shallow sites than in deep sites (Fig. 3a).

The proportions of the major groups of crustaceans in Expt 1 were similar at most locations except O'Brien Bay deep, where there were proportionally fewer gammarids in the contaminated treatment (Fig. 3d). There were a larger proportion of copepods and cumaceans at O'Brien Bay (Fig. 3). In Expt 2, gammarids were dominant at the station locations and the control loca- tions had a more even distribution of crustacean taxa (Fig. 3e,f). However this dominance at station locations had lessened by 12 mo and isopods had increased in abundance and comprised a greater proportion of the crustacean assemblage (Fig. 3f).

In Expt 1, mean densities in recruiting assemblages ranged from $3606 \mathrm{~m}^{-2}$ (mean number of individuals $\mathrm{m}^{-2}$ ) in control sediment at O'Brien Bay deep to $31527 \mathrm{~m}^{-2}$ in control sediment at Brown Bay shallow (using a $0.5 \mathrm{~mm}$ screen). Densities were higher in the second experiment with a minimum of $4933 \mathrm{~m}^{-2}$ in control sediment at O'Brien Bay-3 and a maximum of $48019 \mathrm{~m}^{-2}$ in control sediment at Brown Bay after 9 mo. By 12 mo, mean abundances at most locations had increased by 2 to 4 times, with densities in contaminated sediment at O'Brien Bay-3 of $19391 \mathrm{~m}^{-2}$ (from $7002 \mathrm{~m}^{-2}$ ) and in control sediment at Shannon Bay of $60188 \mathrm{~m}^{-2}$ (from $23241 \mathrm{~m}^{-2}$ ). The densities observed in a survey of surrounding sediments, using cores taken by divers, (on a $1 \mathrm{~mm}$ screen) ranged from $10900 \mathrm{~m}^{-2}$ at $\mathrm{O}^{\prime}$ Brien Bay-3 to $40400 \mathrm{~m}^{-2}$ at Brown Bay (Stark et al. 2003a). Examination of abundances in surrounding sediment in 
whole samples $(1 \mathrm{~mm}+500 \mu \mathrm{m})$ revealed that on average the $1 \mathrm{~mm}$ component contained $70 \%$ of the total (range: 65 to $80 \%$; Stark 2001), which would make densities attained in this experiment comparable to those in surrounding sediments. Original data are available at http://www.aad.gov.au/metadata.

\section{Experiment 1}

Assemblages recruiting to defaunated sediment were significantly different at each combination of location and depth (termed 'site') and there was a sig-

Table 1. Expt 1. NP-MANOVA on Bray-Curtis distances for assemblages colonising control and contaminated sediment at 4 locations (based on 4th-roottransformed abundances)

\begin{tabular}{|c|c|c|c|c|c|c|}
\hline \multicolumn{2}{|l|}{ Source } & $\mathrm{df}$ & MS & $F$ & $\mathrm{p}$ & $F$ vs \\
\hline \multicolumn{2}{|l|}{ Site } & 3 & 10266.41 & 15.50 & 0.0002 & Residual \\
\hline \multicolumn{2}{|c|}{ Sediment } & 1 & 2122.35 & 3.20 & 0.0002 & Residual \\
\hline \multicolumn{2}{|c|}{ Site $\times$ Sediment } & 3 & 2180.33 & 3.29 & 0.0002 & Residual \\
\hline \multicolumn{2}{|c|}{ Residual } & 48 & 662.55 & & & \\
\hline \multicolumn{7}{|c|}{$\begin{array}{l}\text { Pairwise a posteriori comparisons between control and contaminated } \\
\text { sediment within sites }\end{array}$} \\
\hline \multirow{2}{*}{\multicolumn{2}{|c|}{ Site }} & \multicolumn{2}{|c|}{ Untransformed } & \multicolumn{3}{|c|}{ 4th-root-transformed } \\
\hline & & $t$ & $\mathrm{p}$ & & $t$ & $\mathrm{p}$ \\
\hline \multirow[t]{2}{*}{ Brown Bay } & shallow & 1.84 & 0.023 & & 1.15 & 0.21 \\
\hline & deep & 1.4 & 0.028 & & 1.43 & 0.008 \\
\hline \multirow[t]{2}{*}{ O'Brien Bay } & shallow & 4.2 & 0.0002 & & 2.71 & 0.0004 \\
\hline & deep & 1.95 & 0.0004 & & 1.85 & 0.0002 \\
\hline
\end{tabular}

nificant multivariate interaction between site and sediment type (Table 1), which related to differing effects of sediment type within each site. The 4 -factor univariate analysis indicated many significant interactions between the effects of location, depth and sediment type for many taxa (Table 2).

Effect of location. Both nMDS and CAP ordinations show clear distinction among sites, but the distinction among groups is clearer in the CAP ordination, particularly for control and contaminated sediment (Fig. 4). Differences among sites were greater than that due to sediment type and were consistent across both sediment types (Fig. 4).

Mean total abundance and mean number of taxa were significantly greater at Brown Bay than at O'Brien Bay, but this was influenced by greater abundance at Brown Bay shallow. There was no significant difference in Shannon-Wiener diversity $\left(H^{\prime}\right)$, species richness $(d)$ or evenness $\left(J^{\prime}\right)$ between the 2 locations (Table 2, Fig. 5). Abundances of many taxa were significantly greater at Brown than at O'Brien Bay (Table 2, Fig. 5). The species identified as contributing most to the differences between O'Brien Bay and Brown Bay (by SIMPER) were the gammarids Orchomenella franklini, Methalimedon nordenskjoldi, Shraderia gracilis, Heterophoxus videns, the gastropod

Table 2. Expt 1. Summary of analyses of variance results. BB: Brown Bay; OB: O'Brien Bay; P: contaminated sediment; C: control sediment; S: shallow $(15 \mathrm{~m}) ; \mathrm{D}$ : deep $(25 \mathrm{~m}) .{ }^{*}$ significant at $\mathrm{p}=0.05,{ }^{* *}$ significant at $\mathrm{p}=0.01,{ }^{* * *}$ significant at $\mathrm{p}=0.001$; -: not significant

\begin{tabular}{|c|c|c|c|c|c|c|c|c|}
\hline Taxa & Location & Sediment & Depth & Tray & $\mathrm{Lo} \times \mathrm{Se}$ & $\mathrm{Lo} \times \mathrm{De}$ & $\mathrm{Se} \times \mathrm{De}$ & $\mathrm{Lo} \times \mathrm{Se} \times \mathrm{De}$ \\
\hline Total taxa & $\mathrm{BB}>\mathrm{OB}^{*}$ & - & - & - & - & - & - & - \\
\hline Total individuals & $\mathrm{BB}>\mathrm{OB}^{* *}$ & - & $\mathrm{S}>\mathrm{D}^{* * *}$ & $* * *$ & - & - & - & - \\
\hline Shannon diversity $\left(H^{\prime}\right)$ & - & - & $\mathrm{D}>\mathrm{S}^{* *}$ & ${ }^{*}$ & - & - & - & - \\
\hline Richness $(d)$ & - & - & $\mathrm{D}>\mathrm{S}^{*}$ & - & * & - & - & - \\
\hline Evenness $\left(J^{\prime}\right)$ & - & - & $\mathrm{D}>\mathrm{S}^{* *}$ & ${ }^{*}$ & - & - & - & - \\
\hline Crustaceans & $\mathrm{BB}>\mathrm{OB}^{* * *}$ & - & $\mathrm{S}>\mathrm{D}^{* *}$ & $* * *$ & - & * & - & - \\
\hline Gammarids & $\mathrm{BB}>\mathrm{OB}^{* * *}$ & - & $\mathrm{S}>\mathrm{D}^{* * *}$ & - & - & - & - & - \\
\hline Orchomenella franklini & $\mathrm{BB}>\mathrm{OB}^{* * *}$ & - & $\mathrm{S}>\mathrm{D}^{* * *}$ & $* *$ & - & ${ }^{* *}$ & & * \\
\hline Methalimedon nordenskjoldi & $\mathrm{BB}>\mathrm{OB}^{* * *}$ & $\mathrm{C}>\mathrm{P}^{* *}$ & $\mathrm{~S}>\mathrm{D}^{* * *}$ & - & - & - & ** & * \\
\hline Tanaids & $\mathrm{BB}>\mathrm{OB}^{* *}$ & - & - & $* * *$ & * & - & $*$ & - \\
\hline Ostracods & $\mathrm{BB}>\mathrm{OB}^{* *}$ & - & - & - & - & - & - & - \\
\hline Cumaceans & $\mathrm{OB}>\mathrm{BB}^{*}$ & - & - & * & - & * & - & - \\
\hline Isopods & $\mathrm{BB}>\mathrm{OB}^{* *}$ & - & - & - & ** & - & - & - \\
\hline Austrosignum cf. grande & $\mathrm{BB}>\mathrm{OB}^{*}$ & - & $\mathrm{S}>\mathrm{D}^{*}$ & - & - & - & - & - \\
\hline Polychaetes & - & - & $\mathrm{S}>\mathrm{D}^{* * *}$ & - & * & - & - & - \\
\hline Dorvelleids & $\mathrm{OB}>\mathrm{BB}^{* *}$ & $\mathrm{P}>\mathrm{C}^{*}$ & $\mathrm{~S}>\mathrm{D}^{* * *}$ & - & - & $* * *$ & $* *$ & - \\
\hline Polynoids & $\mathrm{OB}>\mathrm{BB}^{* *}$ & $\mathrm{P}>\mathrm{C}^{*}$ & - & - & $* *$ & - & $*$ & * \\
\hline Gastropods & - & - & $\mathrm{S}>\mathrm{D}^{* * *}$ & $* *$ & $*$ & & & * \\
\hline Echinoderms & - & - & - & - & - & - & - & - \\
\hline
\end{tabular}


(a) NMDS ordination, stress $=0.16$

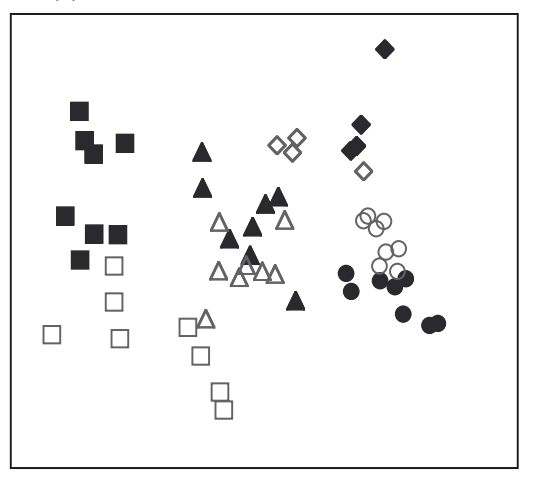

Brown Bay Control Shallow
Brown Bay Control Deep
O'Brien Bay Control Shallow
O'Brien Bay Control Deep

Fig. 4. Expt 1. Ordinations of assemblages in transplanted sediments. (a) NMDS ordination of all samples, data 4th-root-transformed; (b) CAP ordination of all samples (b) CAP ordination

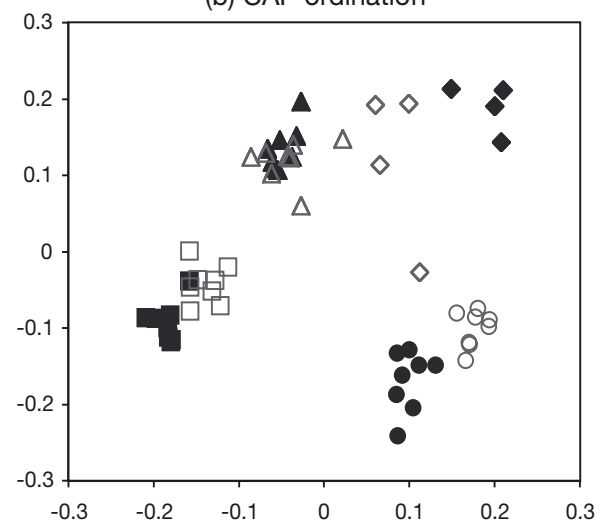

o Brown Bay Polluted Shallow $\triangle$ Brown Bay Polluted Deep $\diamond$ O’Brien Bay Polluted Shallow $\square$ O’Brien Bay Polluted Deep
Skenella paludionoides, the tanaid genus Nototanais, nemerteans, and the isopod Austrosignum $c f$. grande, all of which were more abundant in Brown Bay and contributed $\sim 39 \%$ to the dissimilarity between the 2 locations. The taxa that were more abundant at O'Brien Bay were nematodes, cumaceans, the ostracod Scleroconcha sp. I, 2 gammarid species (Paroediceroides sinuatus and Monoculedes sp. VIIA) and 3 families of polychaetes (nephtyids, polynoids and syllids).

Effect of contaminated sediment. NP-MANOVA indicated significant differences between assemblages in control and contaminated sediment and a posteriori comparisons indicated these were greatest at O'Brien Bay (Table 1). Differences between
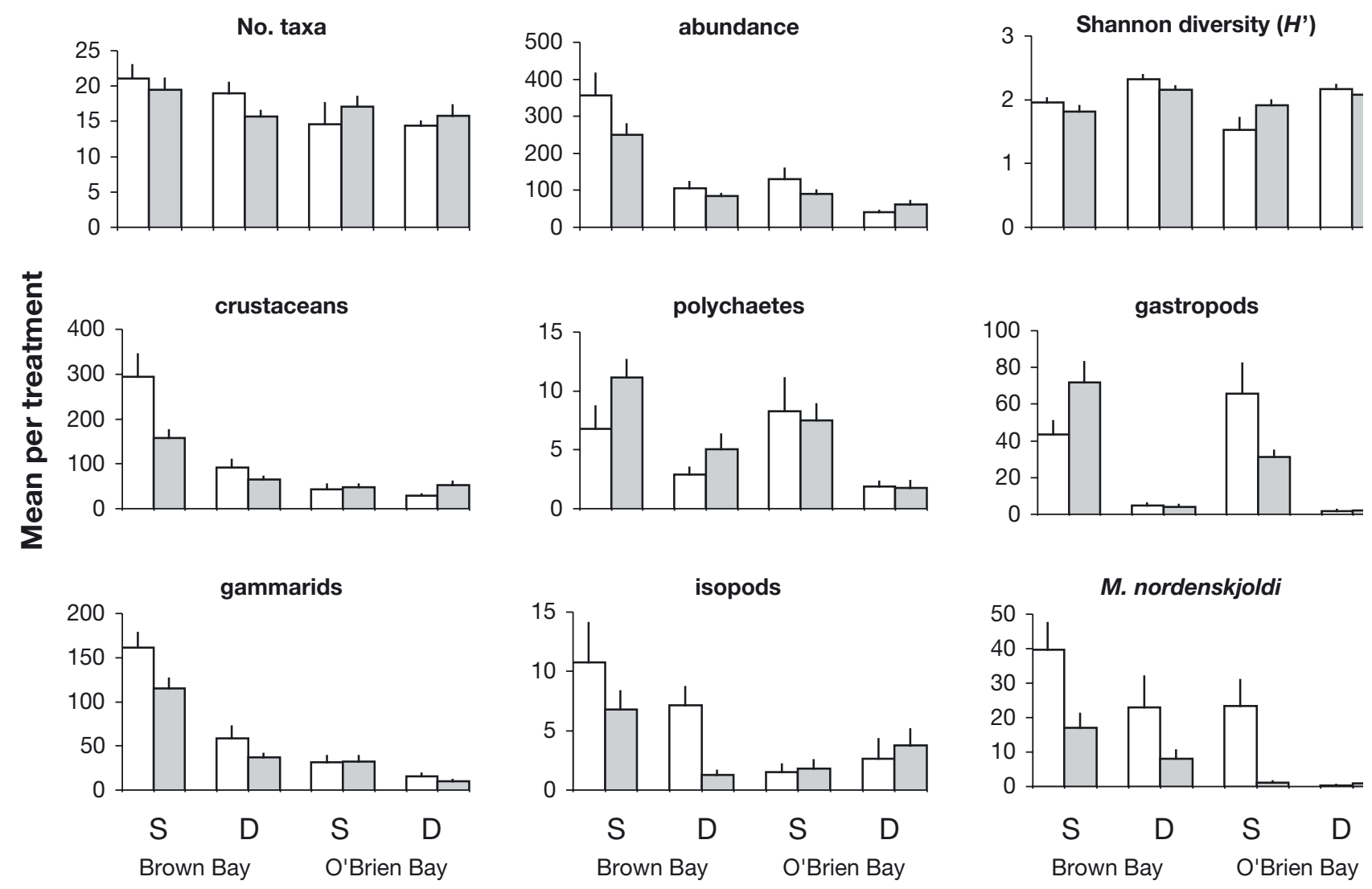

Fig. 5. Expt 1. Mean (+SE) abundance of various taxa and diversity within each treatment. $\mathrm{n}=8$, except at $\mathrm{O}^{\prime}$ Brien Bay shallow location where $\mathrm{n}=4 \mathrm{~S}$ : shallow site; $\mathrm{D}$ : deep site; open bars: control sediment; shaded bars: contaminated sediment; M. nordeskjoldi: Methalimedon nordeskjoldi 
assemblages in the 2 sediment types within each site are apparent in both unconstrained nMDS and constrained CAP ordinations (Fig. 4). The species contributing to differences between control and contaminated sediment treatments (from SIMPER analysis) were variable between locations and depths, but consisted mainly of crustaceans (gammarids, tanaids and isopods) and, in particular, the gammarids Methalimedon nordenskjoldi and Schraderia gracilis, which were generally more abundant in control sediment.

While differences among assemblages in control and contaminated sediment were clear, patterns of differences for individual taxa were complex and difficult to interpret. Sediment effects on individual taxa were mostly confined to 1 location or depth within a location. The most significant overall effect was for the gammarid Methalimedon nordenskjoldi, which was more abundant in control sediment (Fig. 5). At Brown Bay the total number of taxa recorded in control sediment was greater than in contaminated sediment at both sites ( shallow: control $=44$, contaminated $=39$; deep: control $=36$, contaminated $=33$ ). Cumaceans were present in all control sediment in very low densities but the only contaminated sediment in which they were present was from the O'Brien Bay deep site. Polychaetes were more abundant in contaminated sediment at Brown Bay (Fig. 5). When the number of taxa were pooled in each tray and analysed by 2 -factor ANOVA (location and sediment type), the total number of gammarid and isopod taxa were greater in control sediment than in contaminated sediment (ANOVA, gammarid taxa: $F=9.00, \mathrm{p}=0.01$; isopod taxa: $F=5.12, \mathrm{p}=0.04$; SNK $\mathrm{p}<0.05$ ).

Effect of depth. The effect of depth is also apparent in the NMDS and CAP ordinations, with all deep samples on the left of the ordination and the shallow on the right (Fig. 4). Recruitment was greater at shallow sites than at deep sites, but this was influenced overall by greater recruitment at the Brown Bay shallow site than at all others. Abundances of some taxa, including total individuals, gastropods and polychaetes were significantly greater at the shallow sites (Table 2, Fig. 5). The deep sites had significantly greater Shannon diversity $\left(H^{\prime}\right)$, species richness $(d)$ and evenness $\left(J^{\prime}\right)$ (Table 2, Fig. 5). Differences in abundances between depths were variable and often only at 1 site or in 1 sediment type.

Variability. The level of assemblage variability between samples as measured by the multivariate relative dispersion (RD) indicated that assemblages in O'Brien Bay $(\mathrm{RD}=1.45)$ were more variable than in Brown Bay $(\mathrm{RD}=0.75)$; deep assemblages $(\mathrm{RD}=1.15)$ were more variable than shallow $(\mathrm{RD}=0.72)$; and assemblages in control sediment $(\mathrm{RD}=1.10)$ were more variable than those in contaminated sediment $(\mathrm{RD}=$ 0.90). Differences in assemblage variability related to sediment type were further confirmed by examination of the slope of the relationship between log (variance + 1) and $\log ($ mean +1$)$ for each taxon. There was greater variability within trays of control sediment than trays of contaminated sediment. The slope coefficient $(b)$ was less for fauna in contaminated sediments than in control sediments for all locations except O'Brien Bay deep (Brown Bay: shallow, control $b=1.75$, contaminated $b=1.48$; deep, control $b=1.57$, contaminated $b=$ 1.42; O'Brien Bay: shallow, control $b=1.64$, contaminated $b=1.36$; deep, control $b=1.48$, contaminated $b=$ 1.63). Differences among slopes were not analysed further because of potential correlations among species within each sample (Chapman et al. 1995).

\section{Experiment 2}

Expt 2 confirmed significant differences in recruiting assemblages between locations and between control and contaminated sediment, with a significant interaction between location and sediment type (Table 3 ). The multivariate interaction again only related to varying differences between control and
NMDS, 9 mo, stress $=0.17$

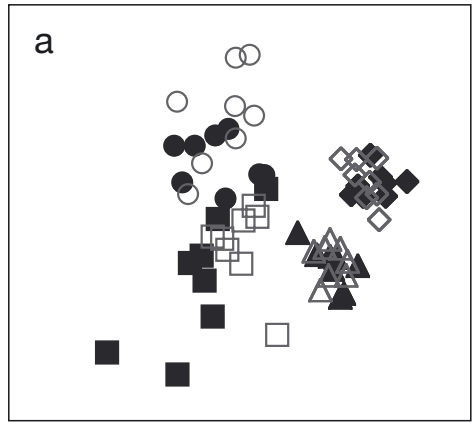

NMDS, 12 mo, stress $=0.16$

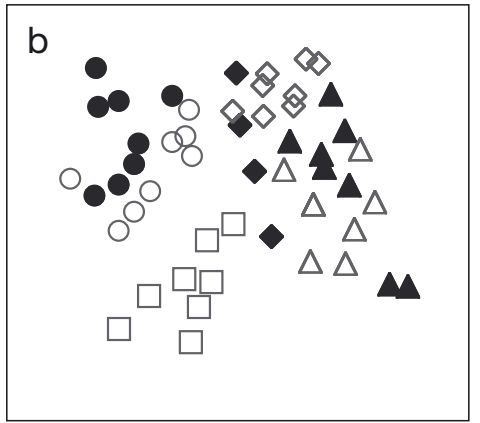

- Brown Bay control

$\diamond$ Brown Bay polluted

$\triangle$ Shannon Bay control

$\triangle$ Shannon Bay polluted

- O'Brien Bay 2 control

- O’Brien Bay 2 polluted

-O'Brien Bay 3 control

$\square$ O’Brien Bay 3 polluted
Fig. 6. Expt 2. NMDS ordinations of assemblages recruiting to each location at 9 and $12 \mathrm{mo}$ 
contaminated sediment within different locations. The NMDS ordinations at 9 mo and at 12 mo revealed the 2 a priori defined groups, with the control locations in 1 group on the left of the ordinations and the station locations on the right (Fig. 6a,b).
These 2 groups were significantly different (ANOSIM: $\mathrm{R}=0.69, \mathrm{p}<0.001$ ).

Effect of location. As in Expt 1, location had the strongest effect on assemblage patterns and patterns of abundance of individual taxa. Assemblages were sig-

Table 3. Expt 2. NP-MANOVA on Bray-Curtis distances for assemblages colonising control and contaminated sediment at 4 locations (based on 4th-root-transformed abundances). na = not analysed due to missing treatment

\begin{tabular}{|c|c|c|c|c|c|c|c|c|}
\hline \multirow{2}{*}{ Source } & \multicolumn{4}{|c|}{$9 \mathrm{mo} \longrightarrow$} & \multirow[b]{2}{*}{$\mathrm{df}$} & \multirow{2}{*}{$\overline{\mathrm{MS}}$} & \multicolumn{2}{|c|}{$12 \mathrm{mo}$} \\
\hline & $\mathrm{df}$ & MS & $F$ & $\mathrm{p}$ & & & $F$ & $\mathrm{p}$ \\
\hline Location (Loc) & 3 & 29688.95 & 37.19 & 0.0001 & 2 & 14336.17 & 17.46 & 0.0001 \\
\hline Sediment (Sed) & 1 & 1345.04 & 1.69 & 0.046 & 1 & 2007.64 & 2.44 & 0.019 \\
\hline Loc $\times$ Sed & 3 & 2448.14 & 3.07 & 0.0001 & 2 & 6154.39 & 7.49 & 0.0001 \\
\hline Residual & 56 & 798.26 & & & 38 & 821.16 & & \\
\hline Total & 63 & & & & 43 & & & \\
\hline \multicolumn{9}{|c|}{ Pairwise a posteriori comparisons between each location } \\
\hline & & 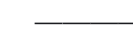 & $-9 \mathrm{mc}$ & - & 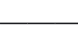 & $-12 \mathrm{mo}$ & 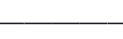 & \\
\hline & & $t$ & $\mathrm{p}$ & avg. dissimilarity & $t$ & $\mathrm{p}$ & \multicolumn{2}{|c|}{ avg. dissimilarity } \\
\hline Brown vs Shannon & & 5.47 & 0.0002 & 60.06 & 2.44 & 0.0002 & \\
\hline Brown vs O'Brien-2 & & 6.67 & 0.0002 & 83.35 & 3.89 & 0.0001 & \multicolumn{2}{|c|}{60.25} \\
\hline Brown vs O'Brien-3 & & 6.96 & 0.0002 & 83.40 & & & & \\
\hline Shannon vs O'Brien-2 & & 6.27 & 0.0002 & 77.77 & 4.42 & 0.0001 & \multirow{3}{*}{\multicolumn{2}{|c|}{66.36}} \\
\hline Shannon vs O'Brien-3 & & 6.13 & 0.0002 & 74.05 & & & & \\
\hline O'Brien-2 vs O'Brien-3 & & 2.53 & 0.0002 & 53.43 & & & & \\
\hline \multicolumn{9}{|c|}{ Pairwise a posteriori comparisons between control and contaminated sediment at each location } \\
\hline & & \multicolumn{2}{|c|}{$9 \mathrm{mo}-$} & & \multicolumn{2}{|c|}{$-12 \mathrm{mo}-$} & & \\
\hline & & $t$ & $\mathrm{p}$ & & $t$ & $\mathrm{p}$ & & \\
\hline Brown Bay & & 1.58 & 0.007 & & 3.06 & 0.0002 & & \\
\hline Shannon Bay & & 1.50 & 0.067 & & 2.11 & 0.009 & & \\
\hline O'Brien Bay-2 & & 1.59 & 0.002 & & 2.02 & 0.008 & & \\
\hline O'Brien Bay-3 & & 1.85 & 0.016 & & na & na & & \\
\hline
\end{tabular}

Table 4. Expt 2. Summary of significant results from 4-factor ANOVAs and SNK tests. ${ }^{*}$ significant at $\mathrm{p}<0.05,{ }^{* *} \mathrm{p}<0.01$, ${ }^{* * *} \mathrm{p}<0.001, \mathrm{~T} 1: 9 \mathrm{mo} ; \mathrm{T} 2: 12 \mathrm{mo}$

\begin{tabular}{|c|c|c|c|c|c|c|c|c|}
\hline & Time & Location & Sediment & Tray & $\begin{array}{l}\text { Time } \\
\times \text { Loc }\end{array}$ & $\begin{array}{l}\text { Time } \\
\times \text { Sed }\end{array}$ & $\begin{array}{c}\text { Loc } \\
\times \text { Sed }\end{array}$ & $\begin{array}{c}\text { Time } \times \\
\text { Loc } \times \text { Sed }\end{array}$ \\
\hline Total taxa & $\mathrm{T} 2>\mathrm{T} 1{ }^{* * *}$ & $\mathrm{BB}>\mathrm{SB}>\mathrm{OB} 2>\mathrm{OB}^{* * *}$ & ns & ns & ns & ns & ns & ns \\
\hline Total individuals & $\mathrm{T} 2>\mathrm{T} 1{ }^{* * *}$ & $\mathrm{BB}>\mathrm{SB}=\mathrm{OB} 2>\mathrm{OB}^{* * *}$ & $\mathrm{P}>\mathrm{C}^{*}$ & $* * *$ & $* * *$ & ns & ${ }^{* *}$ & ${ }^{*}$ \\
\hline Diversity $\left(H^{\prime}\right)$ & ns & $\mathrm{BB}=\mathrm{OB} 2>\mathrm{SB}=\mathrm{OB} 3^{* * *}$ & ns & $* * *$ & $* *$ & ns & ns & ns \\
\hline Richness $(d)$ & $\mathrm{T} 2>\mathrm{T} 11^{* *}$ & $\mathrm{BB}=\mathrm{OB} 2>\mathrm{SB}=\mathrm{OB}^{* * *}$ & ns & ns & ns & ns & ns & ns \\
\hline Evenness $\left(J^{\prime}\right)$ & ns & $\mathrm{OB} 2=\mathrm{BB}=\mathrm{OB} 3>\mathrm{SB}^{* * *}$ & ns & $* * *$ & $* * *$ & ns & $*$ & ns \\
\hline Crustaceans & $\mathrm{T} 2>\mathrm{T} 11^{* *}$ & $\mathrm{BB}>\mathrm{SB}>\mathrm{OB} 2>\mathrm{OB}^{* * *}$ & $\mathrm{P}>\mathrm{C}^{*}$ & $* * *$ & $* *$ & ns & $*$ & ${ }^{*}$ \\
\hline Gammarids & ns & $\mathrm{BB}=\mathrm{SB}>\mathrm{OB} 2>\mathrm{OB}^{* * *}$ & ns & ${ }^{*}$ & ${ }^{*}$ & ns & $*$ & * \\
\hline Orchomenella franklini & $\mathrm{T} 1>\mathrm{T} 2 *$ & $\mathrm{SB}>\mathrm{BB}>\mathrm{OB} 3>\mathrm{OB} 2^{* * *}$ & ns & $* * *$ & ns & ns & ns & ${ }^{*}$ \\
\hline Methalimedon nordenskjold & di ns & $\mathrm{BB}>\mathrm{SB}>\mathrm{OB} 3=\mathrm{OB} 2^{* * *}$ & ns & $* * *$ & $* *$ & ns & ns & ns \\
\hline Isopods & $\mathrm{T} 2>\mathrm{T}^{* * *}$ & $\mathrm{BB}>\mathrm{OB} 2=\mathrm{SB}>\mathrm{OB}^{* * *}$ & ns & ns & ns & ns & $* * *$ & ns \\
\hline Ostracods & ns & $\mathrm{BB}>\mathrm{SB}>\mathrm{OB} 3=\mathrm{OB} 2^{* * *}$ & ns & $* * *$ & $* * *$ & ns & $\mathrm{ns}$ & ns \\
\hline Tanaids & ns & $\mathrm{BB}>\mathrm{SB}>\mathrm{OB} 2=\mathrm{OB}^{* * *}$ & ns & $* * *$ & ns & ns & ns & ns \\
\hline Polychaetes & ns & $\mathrm{BB}>\mathrm{OB} 2>\mathrm{SB}=\mathrm{OB} 3^{* * *}$ & ns & ns & $* * *$ & ${ }^{*}$ & $*$ & ns \\
\hline Capitellids & ns & $\mathrm{BB}>\mathrm{SB}=\mathrm{OB} 2=\mathrm{OB}^{* * *}$ & ns & ns & ns & ns & ns & ns \\
\hline Gastropods & $\mathrm{T} 2>\mathrm{T} 1 * * *$ & $\mathrm{SB}=\mathrm{OB} 2>\mathrm{BB}=\mathrm{OB} 3^{* *}$ & ns & $* * *$ & ${ }^{* *}$ & ns & $* * *$ & ${ }^{*}$ \\
\hline Onuba gelida & ns & $\mathrm{OB} 2>\mathrm{OB} 3=\mathrm{BB}>\mathrm{SB}^{* * *}$ & $\mathrm{C}>\mathrm{P}^{*}$ & $* *$ & ns & ns & ns & ns \\
\hline
\end{tabular}


nificantly different from each other at all locations, with the greatest similarity between the 2 locations within O'Brien Bay (Table 3). Multivariate patterns of differences between locations were similar at 9 and 12 mo, but assemblages at Brown Bay and Shannon Bay were slightly more variable at $12 \mathrm{mo}$, as apparent in the greater spread of samples from these locations in the 12 mo NMDS ordination (Fig. 6). The mean abundance of most taxa were significantly greater at the station locations than at the control locations at 9 mo but by 12 mo differences had decreased (Table 4, Fig. 7). Diversity, evenness and richness did not show any pattern relating to the station locations; however abundances of some individual taxa did, e.g. capitellid polychaetes and crustaceans, mainly gammarids, e.g. Orchomenella franklini, Methalimedon nordenskjoldi and $O$. pinguides were significantly more abundant at station locations, Brown Bay and Shannon Bay (Fig. 7). The gastropod Onoba gelida was more abundant at the control locations O'Brien Bay-2 and -3 (Table 4, Fig. 7).
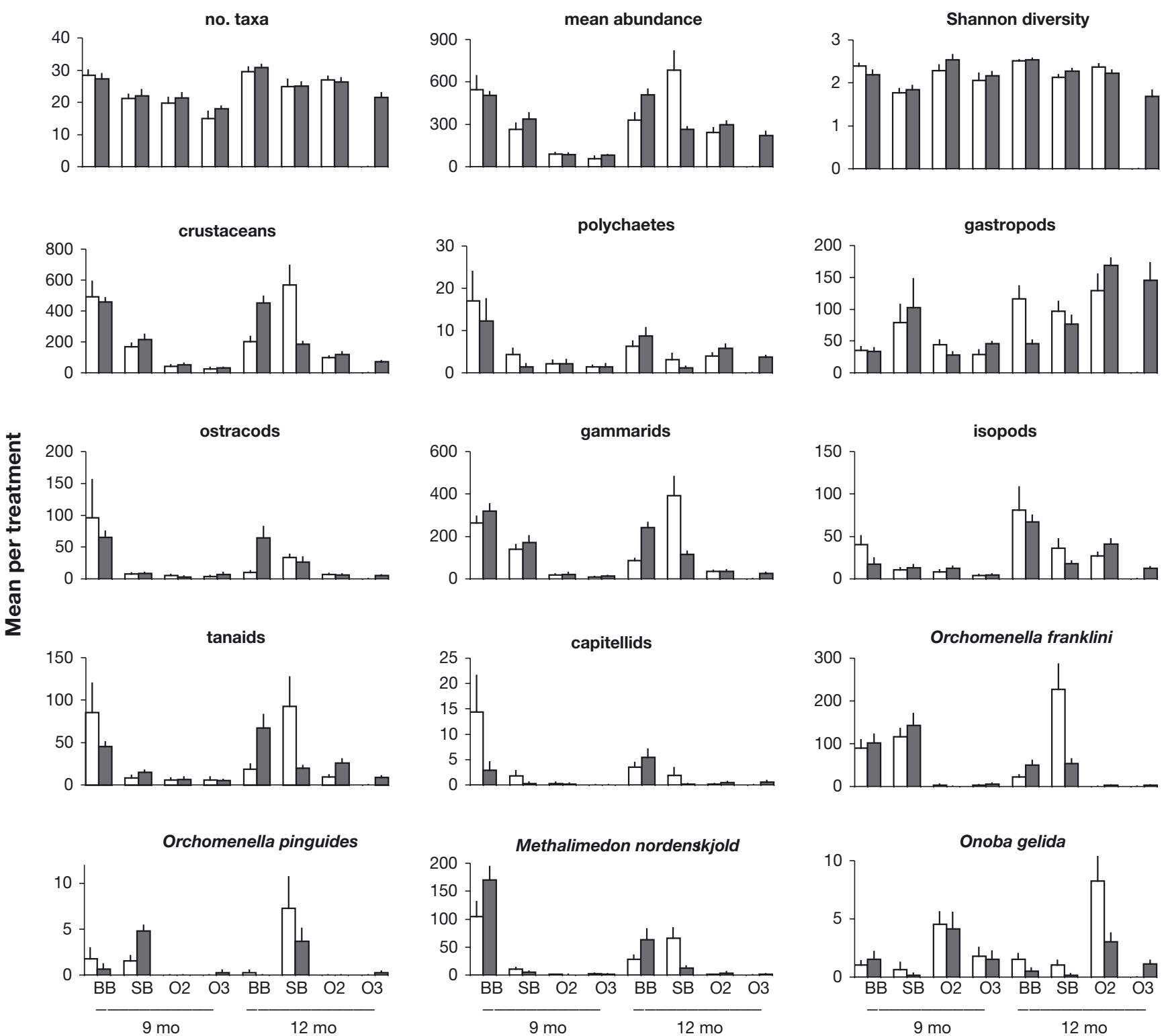

Fig. 7. Expt 2. Mean (+SE) abundance of various taxa and diversity per treatment at 9 and 12 mo. $\mathrm{n}=8$, except for control sediment at Brown Bay and O'Brien Bay-3 at 12 mo where n = 4. BB: Brown Bay; SB: Shannon Bay; O2: O'Brien Bay-2; O3: O'Brien Bay-3. Open bars: control sediment; shaded bars: contaminated sediment. Data missing from control 12 mo at O'Brien Bay-3 due to loss of trays through icebergs 

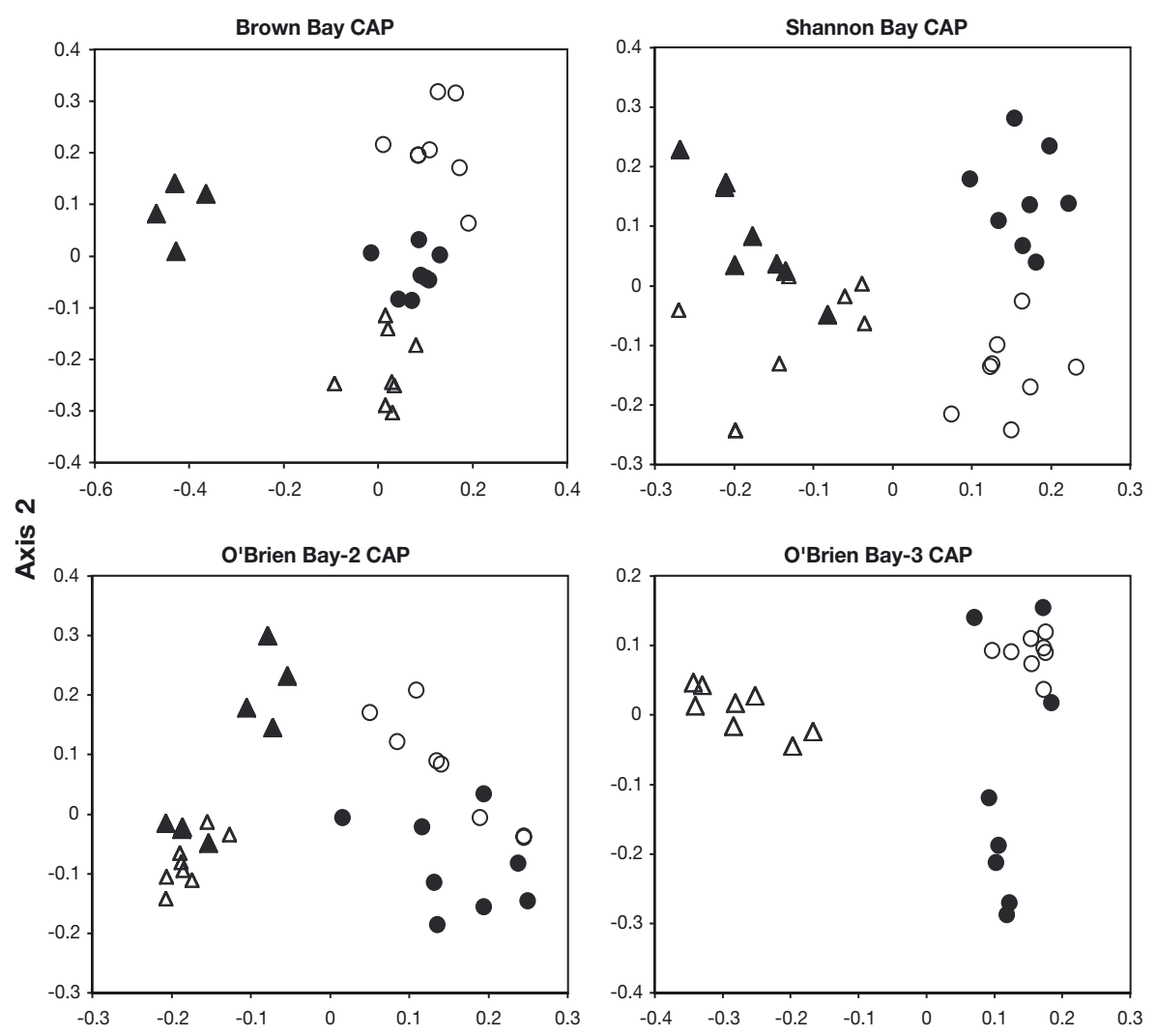

Axis 1

\begin{tabular}{|ll}
\hline - Control 9 mo & o Polluted 9 mo \\
$\Delta$ Control 12 mo & $\Delta$ Polluted 12 mo
\end{tabular}

Fig. 8. Expt 2. CAP ordinations of assemblages recruiting based on Bray-Curtis dissimilarities of 4 th-root-transformed abundance

Effect of sediment contamination. NP-MANOVA indicated significant differences between control and contaminated sediment at 9 and 12 mo (Table 3). A posteriori comparisons of sediment type revealed as- semblages in control and contaminated sediment to be significantly different at all locations at $9 \mathrm{mo}$ (except Shannon Bay) and 12 mo and that differences were greater by 12 mo (Table 3). Separate CAP ordinations of each location in Expt 2 reveal clear differences between assemblages in control and contaminated sediment at both times (Fig. 8).

Differences in the abundances of individual taxa between the 2 sediment types were very complex and difficult to interpret due to many significant interaction terms between sediment type and either or both time and location (Table 4, Fig. 7). For example, there were large but contrasting differences in the abundance of crustaceans in control and contaminated sediment at Brown Bay and Shannon Bay at 12 mo (Fig. 7). Where effects of contaminated sediment are evident they are often restricted to 1 time or 1 location within that time (Fig. 7).

Significant time $\times$ location $\times$ sediment interactions are summarised in Table 5. These interactions show that at station locations, assemblages in control sediment changed more over time than those in contaminated sediment. There were a greater number of differences between 9 and 12 mo at Brown Bay and Shannon Bay for control sediment than for contaminated sediment (Table 5). There was roughly an equal number of changes through time for control and contami-

Table 5. Expt 2. Results of SNK tests for Time $\times$ (Location $\times$ Sediment) interactions. Differences between times in each sediment type at each location. T1: 9 mo; T2: 12 mo; C: control; P: polluted; ns: not significant

\begin{tabular}{|c|c|c|c|c|c|c|c|c|}
\hline \multirow[t]{2}{*}{ Taxa } & \multicolumn{2}{|c|}{ Brown Bay } & \multicolumn{2}{|c|}{ Shannon Bay } & \multicolumn{2}{|c|}{ O'Brien Bay-2 } & \multicolumn{2}{|c|}{ O'Brien Bay-3 } \\
\hline & $\mathrm{C}$ & $\mathrm{P}$ & $\mathrm{C}$ & $\mathrm{P}$ & $\mathrm{C}$ & $\mathrm{P}$ & C & $\mathrm{P}$ \\
\hline Total individuals & ns & ns & $\mathrm{T} 2>\mathrm{T} 1$ & ns & $\mathrm{T} 2>\mathrm{T} 1$ & $\mathrm{~T} 2>\mathrm{T} 1$ & - & $\mathrm{T} 2>\mathrm{T} 1$ \\
\hline Crustaceans & $\mathrm{T} 1>\mathrm{T} 2$ & ns & $\mathrm{T} 2>\mathrm{T} 1$ & ns & $\mathrm{T} 2>\mathrm{T} 1$ & $\mathrm{~T} 2>\mathrm{T} 1$ & - & $\mathrm{T} 2>\mathrm{T} 1$ \\
\hline Gammarids & $\mathrm{T} 1>\mathrm{T} 2$ & ns & $\mathrm{T} 2>\mathrm{T} 1$ & ns & $\mathrm{T} 2>\mathrm{T} 1$ & $\mathrm{~ns}$ & - & $\mathrm{ns}$ \\
\hline Orchomenella franklini & $\mathrm{T} 1>\mathrm{T} 2$ & ns & ns & $\mathrm{T} 1>\mathrm{T} 2$ & ns & ns & - & ns \\
\hline Heterophoxus videns & $\mathrm{T} 1>\mathrm{T} 2$ & $\mathrm{~T} 2>\mathrm{T} 1$ & $\mathrm{~T} 2>\mathrm{T} 1$ & $\mathrm{~T} 2>\mathrm{T} 1$ & ns & ns & - & ns \\
\hline Orchomenella sp. IIA & ns & ns & $\mathrm{T} 2>\mathrm{T} 1$ & ns & ns & ns & - & ns \\
\hline Scleroconcha sp. I & $\mathrm{T} 1>\mathrm{T} 2$ & ns & $\mathrm{T} 2>\mathrm{T} 1$ & $\mathrm{~T} 2>\mathrm{T} 1$ & ns & ns & - & $\mathrm{T} 1>\mathrm{T} 2$ \\
\hline Gastropods & $\mathrm{T} 2>\mathrm{T} 1$ & ns & ns & ns & $\mathrm{T} 2>\mathrm{T} 1$ & $\mathrm{~T} 2>\mathrm{T} 1$ & - & $\mathrm{T} 2>\mathrm{T} 1$ \\
\hline Onuba turqueti & ns & ns & ns & ns & ns & $\mathrm{T} 2>\mathrm{T} 1$ & - & $\mathrm{T} 1>\mathrm{T} 2$ \\
\hline Skenella paludionoides & $\mathrm{T} 2>\mathrm{T} 1$ & ns & ns & ns & $\mathrm{T} 2>\mathrm{T} 1$ & $\mathrm{~T} 2>\mathrm{T} 1$ & - & $\mathrm{T} 2>\mathrm{T} 1$ \\
\hline
\end{tabular}


nated sediment at O'Brien Bay-2 (Table 5-the control treatment was lost from O'Brien Bay-3 at 12 mo).

Temporal effects. Assemblages changed significantly from 9 to 12 mo at Brown Bay (ANOSIM: $\mathrm{R}=0.51, \mathrm{p}<0.001)$, Shannon Bay $(\mathrm{R}=0.57, \mathrm{p}<$ $0.001)$ and $\mathrm{O}^{\prime}$ Brien Bay-2 $(\mathrm{R}=0.42, \mathrm{p}<0.001)$. CAP ordinations of each location show separation of samples from 9 and 12 mo (Fig. 8). For individual taxa, differences between 9 and 12 mo were common, and overall there was a general increase in the number of taxa, the number of individuals and in the abundance of many major taxa, e.g. crustaceans, gastropods (Table 4, Fig. 7) and echinoderms. Several crustacean taxa decreased in abundance from 9 to 12 mo at Brown Bay (Table 5).

The most abundant species at 9 mo was the gammarid Orchomenella franklini, which appears to be an opportunistic, colonising species at station locations (highly motile, brooder with direct developing young), where it recruited in large densities and also occurs in the in situ assemblages in large densities (Stark 2000, Stark et al. 2003a). Abundances of $O$. franklini had decreased by $12 \mathrm{mo}$, but it was still one of the most dominant species at station locations and occurred in very low densities at control locations (Fig. 7).

Variability. Comparisons of variability of recruiting assemblages between locations showed the station locations to be less variable than the control locations at both sampling times, although by 12 months the difference in variability between the control and station locations was less than at 9 mo (Table 6a). Assemblages at the station locations were slightly more variable at 12 mo than at 9 mo and the control locations were less variable at $12 \mathrm{mo}$ than at 9 mo (Table 6b). Examination of individual locations at 9 and $12 \mathrm{mo}$ confirmed this pattern, with O'Brien Bay-2 and O'Brien-3 showing the greatest change in variability between times and Brown Bay the least (Table 6c). Within each location, however, there was no evidence of any difference in variability between control and contaminated sediment.

Table 6. Index of multivariate dispersion (IMD) values comparing variability between groups. Negative value indicates less variation in first group of comparison

$\begin{array}{cr}\text { a: Station locations vs control locations: } 9 \text { mo } & -0.55 \\ \text { Station locations vs control locations: } 12 \text { mo } & -0.07 \\ \text { b: Control locations: } 9 \text { mo vs } 12 \text { mo } & 0.50 \\ \text { Station locations: } 9 \text { mo vs } 12 \text { mo } & -0.07 \\ \text { c: Brown Bay: } \quad 9 \text { mo vs } 12 \text { mo } & -0.40 \\ \text { Shannon Bay: } \quad 9 \text { mo vs } 12 \text { mo } & -0.51 \\ \text { O'Brien Bay-2: } \quad 9 \text { mo vs } 12 \text { mo } & 0.70 \\ \text { O'Brien Bay-3: } \quad 9 \text { mo vs } 12 \text { mo } & 0.60\end{array}$

\section{DISCUSSION}

These experiments provided causal evidence for the model that differences between assemblages near the Casey waste dump and those in control areas are being caused by contamination from the waste dump. The hypotheses that recruitment and recolonisation of marine sediments would be different among locations and different between control and contaminated sediment were supported. Importantly, there was evidence of general recruitment differences between the station locations (near the waste dump and the sewage outfall) and control locations. However, as both station locations were within Newcomb Bay and both the control locations were within O'Brien Bay, some of the differences among recruiting assemblages may have been due to spatial variation caused by unmeasured differences between the 2 bays, such as currents or sea ice. It is not possible to differrentiate between these 2 competing explanations (disturbance from contamination or spatial variation) without an additional control site outside O'Brien Bay. Previous surveys at Casey, however, sampled control locations outside these 2 bays and found them to be more similar to O'Brien Bay than to Newcomb Bay and that differences were not simply due to different bays (Stark 2000, Stark et al. 2003a). The importance of making comparisons of apparently polluted areas with several controls has been well demonstrated (Fairweather 1988, Underwood 1992, 1993, 1994); however, deployment of these experiments at an undisturbed control location outside O'Brien Bay was not possible because there were no other suitable locations within a safe working distance of the station for diving operations, which were necessary to retrieve the sediments.

Differences between locations were greater than those due to effects of contaminated sediment. Assemblages recruiting to Brown Bay (the location of the waste dump) were the most different from all the other locations, but bore most similarity to Shannon Bay (location of the sewage outfall). These station locations had initially greater recruitment (greater number of individuals after $9 \mathrm{mo}$ ) than the controls, and had a greater dominance of highly motile crustaceans, mainly gammarid amphipods of 3 species (Orchomenella franklini, Heterophoxus videns and Methalimedon nordenskjoldi). Brown Bay also had a significantly greater abundance of polychaetes. Large abundances of highly motile species of crustaceans and polychaetes have been found to be characteristic of contaminated and disturbed locations worldwide (Pearson \& Rosenberg 1978, Raman \& Ganapati 1983, Weston 1990, Stark 1998). Lenihan \& Oliver (1995), however, detected a pattern of community response in relation to a pollution gradient in Antarctica at McMurdo Sta- 
tion, of abundances and diversity of infauna increasing with increasing distance from a pollution source (a bay heavily contaminated by hydrocarbons and metals from a dump), with opportunistic polychaetes dominating the most contaminated areas and dense assemblages of motile crustaceans and polychaetes in moderately contaminated areas. In comparison, at Casey we found that abundances are greater at polluted locations, but pollution levels are lower and assemblages appear to be similar to those found at moderately polluted areas at McMurdo (Stark et al. 2003a). Pearson \& Rosenberg (1978) described a response of infauna along an increasing gradient of pollution whereby moderate to high levels of pollution can increase overall abundances of infauna, mainly through large numbers of opportunistic species.

Further evidence that differences at the station locations are due to disturbance is demonstrated by the effects of sediment contamination on recruitment. Concentrations of some metals were up to 2 orders of magnitude greater in the contaminated sediment, sourced from Brown Bay. Differences were more evident for whole assemblages than for individual taxa, which displayed complex and variable patterns of abundance in relation to contaminated sediment. Several studies have demonstrated negative effects of heavy metals on recruitment in soft sediments (Long et al. 1995, Watzin \& Roscigno 1997, Olsgard 1999). Metals have been found to influence the distribution of bivalves via effects on recruitment (McGreer 1982, Bryan \& Gibbs 1983), to reduce recruiting abundances (Watzin \& Roscigno 1997, Olsgard 1999), and also to increase recruiting abundances in some instances, for example gastropods (Watzin \& Roscigno 1997). Metals have also been demonstrated to affect established assemblages (as opposed to recolonisation); for example, crustaceans (mainly gammarids and cumaceans) were the fauna most affected in an experiment examining the effects of copper on in situ soft-sediment assemblages (Morrisey et al. 1996). Hall \& Frid (1995) found that copper reduced the abundances of 4 dominant taxa, and when copper inputs ceased, recovery of the fauna took up to 1 yr with patterns varying between taxa. The response of fauna to pollutants is moderated by factors affecting bioavailability of contaminants such as grain size (Pesch 1979), presence of sulphides (Di Toro et al. 1990), current flow and hypoxia (Diaz \& Rosenberg 1995). Grain size was very similar between the 2 sediment treatments, but the contaminated sediment had higher total organic carbon (TOC) levels and this may have influenced the differences between them. Recent work by Lenihan et al. (2003) has shown different responses to different contaminants at the level of phyla, with enhanced abundances of annelids in response to organic pollution and decreased abundances of crustaceans and echinoderms in metal-contaminated sediments. As the contaminants in our experiment included metals and TOC, it was not possible to determine which had more influence, and they may have had opposing effects, enhancing recruitment of some taxa and negatively influencing others.

A parallel study at Casey found that sediment artificially contaminated by hydrocarbons had greater effects on recruitment than sediment treated with a complex of metals (Stark et al. 2003c). Hydrocarbon contamination in sediments in Brown Bay (although not measured in the present study) is as much as $\sim 1000 \mathrm{mg} \mathrm{kg}^{-1}$ total petroleum hydrocarbons (Stark et al. 2003b, J. Stark unpubl. data). Demonstrated effects of hydrocarbon contamination in sediment on recruitment of benthic infauna include reduction in species diversity and altered distribution of individuals among species (Bakke et al. 1988, Berge 1990, Bonsdorff et al. 1990). Oil in sediments represents a chemical and physical disturbance that results in primary toxic effects and secondary changes in sediment properties such as organic enrichment, and has been shown to increase densities of meiofauna at low concentrations and reduce densities of macrofauna at increasing concentrations (Spies et al. 1988). Effects may be more pronounced for juveniles and larvae and may affect amphipod embryos in the marsupial stages, leading to reduced juvenile survival (Lindén 1976, Elmgren et al. 1983). Bonsdorff et al. (1990) found negative effects of the water-soluble fraction of North Sea crude oil on population densities of an amphipod, especially the juveniles, but no effect on polychaete recruitment. Following oil spills, recovery of benthic infaunal assemblages has taken many years (Dauvin \& Gentil 1990, Gilfillan et al. 1991, Lee \& Page 1997). It is not possible to determine from this study whether metal, oil or organic carbon contamination of the sediments is responsible for differences between controls and contaminated treatments. These experiments demonstrate that the differences in soft-sediment assemblages observed between locations at Casey are influenced by the modification of recruitment patterns caused by the presence of anthropogenic contamination of the sediments.

These experiments also supported the hypothesis of differences in assemblage variability between control and station locations, which may reflect an environmental impact. Assemblages recruiting to station locations were less spatially variable than controls. Abundances of some taxa in trays of uncontaminated control sediment at station locations were more temporally variable than in trays of contaminated sediment. Environmental impacts have the potential not only to affect the mean abundance of populations or species diver- 
sity, but may also alter temporal and spatial variability of populations and assemblages (Underwood 1991, 1992, 1993, 1994, Warwick \& Clarke 1993). These findings concur with previous studies at Casey, which demonstrated less spatial variability in soft-sediment assemblages at polluted locations than at control locations (Stark 2000, Stark et al. 2003a).

Densities of fauna recruiting to the trays were comparable to those in surrounding sediments over 9 to 12 mo. Lenihan \& Oliver (1995) found recruitment to be much slower around McMurdo Station, taking several years to approach densities found in nearby sediments. Recolonisation of defaunated sediments in our experiment appears to be dependent on surrounding assemblages, as they were dominated by the same motile crustaceans recruiting to the experiment, particularly peracarids of the orders Amphipoda, Isopoda and Tanaidacea (Stark 2000, Stark et al. 2003a). Most Antarctic peracarid crustaceans have non-pelagic lecithotrophic development, with brooding and release of fully developed dispersive juveniles throughout the year (Arntz et al. 1994), although some do restrict breeding to particular times of the year (Pearse et al. 1991). Protected, non-pelagic lecithotrophic development of larvae is generally very common in Antarctic benthos (Picken 1980, White 1984). At McMurdo Station, peracarid crustaceans were the major colonists after 1 and 3 yr at a moderately disturbed jetty site, but at a severely polluted location recruitment was dominated by opportunistic polychaetes (Lenihan \& Oliver 1995). Lenihan \& Oliver (1995) similarly concluded that recruitment of disturbed sediments at McMurdo was highly dependent on surrounding populations of motile invertebrates, and many colonists were adult and juvenile immigrants. This has implications for the recovery of impacted assemblages in Antarctica. If remediation of terrestrial waste dumps occurs, as is currently being undertaken at Casey Station, and there is no further input of contaminants to these station locations, there still remains extensive contamination present in the adjacent marine sediments. Hydrocarbons are utilised as an organic food source and degraded by bacterial populations, but metals are more persistent in sediments and could continue to influence recruitment processes in a press effect (sensu Glasby \& Underwood 1996). Furthermore, as recruitment is apparently dominated by local pools of dispersive juveniles and adults, affected assemblages may change, to become more like control assemblages very slowly. Thus local pools of colonisers may be more influential than sediment contamination. Currents have been shown to be very weak around Casey Station, and are largely induced by severe winds when waters are ice-free (Tate et al. 2000). During the winter period of these experiments, surface waters remained ice-covered and current velocities would have been very low. As a consequence, transport and immigration of larvae over long distances is unlikely to have occurred, and recruitment in this experiment is likely to have been controlled by micro-scale processes such as habitat selection and local immigration/dispersal. However, Antarctic benthic invertebrates have been shown to have longer developmental times than in other parts of the world (King \& Riddle 2001), and this could increase their dispersive potential, but also increase their period of embryonic or juvenile exposure to contaminants, a period when they are most sensitive.

Recruitment mechanisms in this experiment included settlement of larvae from the water column and resuspension or active locomotion of fauna from surrounding benthic habitats. Larval settlement onto soft sediments is largely controlled by habitat selection (micro-scale) and passive deposition by hydrodynamic processes (large-scale) (Butman 1987). Surface-active fauna, such as gastropods and polynoid polychaetes, may have been able to crawl into the trays, which may explain the greater proportion of gastropods in the experimental sediments ( 3 to $52 \%$ of individuals) than in the surrounding sediment $(<5 \%$ : Stark 2000 , Stark et al. 2003c). Alternatively the experimental units may have provided enhanced conditions for gastropods, e.g. food or a refuge from predation. Lateral burrowing and immigration from below the surrounding sediment surfaces were eliminated by the tray design, which put the surface of the defaunated sediments approximately $10 \mathrm{~cm}$ above the surrounding substrate. Thus, brooding species without the facility for swimming dispersal or surface activity, such as burrowing polychaetes, may have been partially excluded. Polychaetes were relatively uncommon in this experiment, and were only present in low densities in the surrounding benthic communities. In contrast, many recruitment experiments in soft sediments have found that polychaetes are the dominant colonising fauna, independent of depth and habitat (Mattsson \& Notini 1985, Berge 1990, Snelgrove et al. 1994, Olsgard 1999). Further hydrodynamic effects from setting the trays on top of the sediment, as opposed to burying them flush with the sediment surface, are likely to be very minimal because of the very low current velocities in Antarctic inshore waters as a result of almost year-round ice cover. There was no evidence of scouring or deposition around the trays or in the pots within them.

Manipulating soft-sediment assemblages provides a meaningful way of quantifying and predicting responses to contaminants under realistic conditions (Olsgard 1999). This study indicated that monitoring recruitment into soft sediments has potential for environmental monitoring situations where changes in 
sediment chemistry may be expected as a result of contaminants entering the marine environment. Sources of variability that would need to be accounted for, were the technique to be used for routine monitoring, include spatial variability (both small-scale, between trays, and large-scale, between locations), depth and temporal variation. Similar methods are currently being used at Casey to monitor the remediation of the waste dump.

Acknowledgements. The authors are grateful to T. Ryan, B. Tong, G. Meades, G. Anderson and S. Doust for assistance with setting up the experiments; P. Goldsworthy, A. Tabor, C. King, I. Snape and J. Davidson for diving assistance; S. Pearce and members of the 50th and 51st ANARE expeditions to Casey; the staff of the Australian Antarctic Division in Hobart; S. Stark for assistance with analysis of sediments; R. Simpson, L. Streeting and the administrative staff in the School of Biological Sciences at the University of New England. This work was supported by the Australian Antarctic Division (project 2201) and the University of New England.

\section{LITERATURE CITED}

Ambrose WG (1984a) Influence of residents on the development of a marine soft-bottom community. J Mar Res 42: 633-654

Ambrose WG (1984b) Role of predatory infauna in structuring marine soft-bottom communities. Mar Ecol Prog Ser 17: $109-115$

Anderson MJ (2000) NPMANOVA: a FORTRAN computer program for non-parametric multivariate analysis of variance (for any two-factor ANOVA design) using permutation tests. Department of Statistics, University of Auckland, Auckland

Anderson MJ (2001) A new method of non-parametric multivariate analysis of variance. Austral Ecol 26:32-46

Anderson MJ (2002) CAP: a FORTRAN computer program for canonical analysis of principal coordinates. Department of Statistics, University of Auckland, Auckland

Anderson MJ, Robinson J (2003) Generalised discriminant analysis based on distances. Aust NZ J Stat 45:301-318

Anderson MJ, Willis TJ (2003) Canonical analysis of principal coordinates: a useful method of constrained ordination for ecology. Ecology 84:511-525

Arntz WE, Brey T, Gallardo VA (1994) Antarctic zoobenthos. Oceanogr Mar Biol Annu Rev 32:241-304

Bakke T, Berge JA, Naess K, Oreld F, Reiersen LO, Bryne K (1988) Long term recolonization and chemical change in sediments contaminated with oil-based drill cuttings. In: Engelhardt FR, Ray JP, Gillam AH (eds) Drilling wastes. Elsevier Applied Science, London, p 521-544

Berge JA (1990) Macrofauna recolonization of subtidal sediments: experimental studies on defaunated sediment contaminated with crude oil in two Norwegian fjords with unequal eutrophication status. I. Community responses. Mar Ecol Prog Ser 66:103-115

Bonsdorff E, Bakke T, Pedersen A (1990) Colonization of amphipods and polychaetes to sediments experimentally exposed to oil hydrocarbons. Mar Pollut Bull 7:355-358

Bryan GW, Gibbs PE (1983) Heavy metals in the Fal estuary, Cornwall: a study of long term contamination by mining waste and its effects on estuarine organisms. Occas Mar Biol Assoc UK 2:112

Butman CA (1987) Larval settlement of soft-sediment invertebrates: the spatial scales of pattern explained by active habitat selection and the emerging role of hydrodynamic processes. Oceanogr Mar Biol Annu Rev 25:113-165

Butman CA, Grassle JP (1992) Active habitat selection by Capitella sp. I larvae. I. Two-choice experiments in still water and flume flows. J Mar Res 50:669-715

Caley MJ, Carr MH, Hixon MA, Hughes TP, Jones GP, Menge BA (1996) Recruitment and the local dynamics of open marine populations. Annu Rev Ecol Syst 27:477-500

Chapman MG, Underwood AJ, Skilleter GF (1995) Variability at different spatial scales between a subtidal assemblage exposed to the discharge of sewage and two control assemblages. J Exp Mar Biol Ecol 189:103-122

Clarke KR (1993) Non-parametric multivariate analyses of changes in community structure. Aust J Ecol 18:117-143

Clarke KR, Warwick RM (1994) Change in marine communities: an approach to statistical analysis and interpretation. Natural Environment Research Council, Plymouth Marine Laboratory, Plymouth

Cross WE, Thomson DH (1987) Effects of experimental releases of oil and dispersed oil on Arctic nearshore macrobenthos. I. Infauna. Arctic 40:184-200

Dauvin JC, Gentil F (1990) Conditions of the peracarid populations of subtidal communities in northern Brittany ten years after the Amoco Cadiz oil spill. Mar Pollut Bull 21: $123-130$

Deprez PP, Arens M, Locher H (1999) Identification and preliminary assessment of contaminated sites at Casey Station, Wilkes Land, Antarctica. Polar Rec 35:299-316

Diaz RJ, Rosenberg R (1995) Marine benthic hypoxia: a review of its ecological effects and the behavioural responses of benthic macrofauna. Oceanogr Mar Biol Annu Rev 33:245-303

Di Toro DM, Mahoney JD, Hansen KJ, Scott KJ, Hicks MB, Mayr SM, Redmond MS (1990) Toxicity of cadmium in sediments: the role of acid volatile sulphide. Environ Toxicol Chem 9:1487-1502

Dubilier $\mathrm{N}$ (1988) $\mathrm{H}_{2} \mathrm{~S}$-a settlement cue or toxic substance for Capitella sp. larvae? Biol Bull 174:30-38

Elmgren R, Hansson S, Larsson U, Sundelin B, Boehm PD (1983) The 'Tsesis' oil spill: acute and long-term impact on the benthos. Mar Biol 73:51-65

Fairweather PG (1988) Sewage and the biota on seashores; assessment of impact in relation to natural variability. Environ Monit Assess 14:197-210

Fairweather PG (1991) Implications of 'supply-side' ecology for environmental assessment and management. Trends Ecol Evol 6:60-63

Gilfillan ES, Page DS, Krejsa CM, Hanson SA, Foster JC, Trussell GC, Whalon BS (1991) Use of ordination techniques to follow community succession from oil impact to recovery in the field. Chem Ecol 5:85-97

Glasby TM, Underwood AJ (1996) Sampling to differentiate between pulse and press perturbations. Environ Monit Assess 42:241-252

Glasby TM, Underwood AJ (1998) Determining positions for control locations in environmental studies of estuarine marinas. Mar Ecol Prog Ser 171:1-14

Gray JS (1974) Animal sediment relationships. Oceanogr Mar Biol Annu Rev 12:223-261

Hall JA, Frid CLJ (1995) Responses of estuarine benthic macrofauna in copper contaminated sediments to remediation of sediment quality. Mar Pollut Bull 30:694-700

Hunt HL, Scheibling RE (1997) Role of early post settlement 
mortality in recruitment of benthic marine invertebrates. Mar Ecol Prog Ser 155:269-301

Hyland J, Laur D, Jones J, Shrake J, Cadian D, Harris L (1994) Effects of an oil spill on the soft-bottom macrofauna of Arthur Harbour, Antarctica compared with long term natural change. Antarct Sci 6:37-44

King CK, Riddle MJ (2001) Effects of metal contaminants on the embryonic and larval development of the common Antarctic sea urchin Sterechinus neumayeri (Meissner). Mar Ecol Prog Ser 215:143-154

Lee RF, Page DS (1997) Petroleum hydrocarbons and their effects in subtidal regions after major oil spills. Mar Pollut Bull 34:928-940

Lenihan HS, Oliver JS (1995) Anthropogenic and natural disturbances to marine benthic communities in Antarctica. Ecol Appl 5:311-326

Lenihan HS, Kiest KA, Conlan KE, Slattery PN, Konar BH, Oliver JS (1995) Patterns of survival and behaviour in Antarctic benthic invertebrates exposed to contaminated sediments: field and laboratory bioassay experiments. J Exp Mar Biol Ecol 192:233-255

Lenihan HS, Peterson $\mathrm{CH}$, Kim SL, Conlan KE, Fairey R, McDonald C, Grabowski JH, Oliver JS (2003) Variation in marine benthic community composition allows discrimination of multiple stressors. Mar Ecol Prog Ser 261:63-73

Lindén O (1976) Effects of oil on the reproduction of the amphipod Gammarus oceanicus. Ambio 5:36-37

Long ER, MacDonald DD, Smith SL, Calder FD (1995) Incidence of adverse effects within ranges of chemical concentrations in marine and estuarine sediments. Environ Manag 19:81-97

Mattsson J, Notini M (1985) Experimental recolonization by macrozoobenthos in a bay polluted by municipal sewage, oil and heavy metals compared to an unpolluted Baltic Bay. Ophelia 24:111-124

McArdle BH, Anderson MJ (2001) Fitting multivariate models to community data: a comment on distance based redundancy analysis. Ecology 82:290-297

McGreer ER (1982) Factors affecting the distribution of the bivalve Macoma balthica on a mudflat receiving sewage effluent, Fraser River estuary, British Columbia. Mar Environ Res 7:131-149

Menzie CA (1984) Diminishment of recruitment: a hypothesis concerning impacts on benthic communities. Mar Pollut Bull 15:127-128

Morrisey DJ, Underwood AJ, Howitt L (1996) Effects of copper on the faunas of marine soft sediments: a field experimental study. Mar Biol 125:199-213

Obreski S (1979) Larval colonization strategies in marine benthic invertebrates. Mar Ecol Prog Ser 1:293-300

Olafsson EB, Peterson CH, Ambrose WG (1994) Does recruitment limitation structure populations and communities of macro-invertebrates in marine soft sediments: the significance of pre- and post-settlement processes. Oceanogr Mar Biol Annu Rev 32:65-109

Olsgard F (1999) Effects of copper contamination on recolonisation of subtidal marine soft sediments - an experimental field study. Mar Pollut Bull 38:448-462

Pearse JS, McClintock JB, Bosch I (1991) Reproduction of Antarctic benthic marine invertebrates: tempos, modes and timing. Am Zool 31:65-80

Pearson TH, Rosenberg R (1978) Macrobenthic succession in relation to organic enrichment and pollution of the marine environment. Oceanogr Mar Biol Annu Rev 16:229-311

Pesch CE (1979) Influence of three sediment types on copper toxicity to the polychaete Neanthes arenaceodentata. Mar Biol 52:237-245
Picken GB (1980) Reproductive adaptations of Antarctic benthic invertebrates. In: Bonner WN, Berry RJ (eds) Ecology in the Antarctic. Academic Press, London, p 67-75

Raman AV, Ganapati PN (1983) Pollution effects on ecobiology of benthic polychaetes in Visakhapatnum Harbour (Bay of Bengal). Mar Pollut Bull 14:46-52

Renaud PE, Syster DA, Ambrose JWG (1999) Recruitment patterns of continental shelf benthos off North Carolina, USA: effects of sediment enrichment and impact on community structure. J Exp Mar Biol Ecol 237:89-106

Scouller RC, Stark JS, Snape I, Riddle MJ, Gore DB (2000) Contaminants in the Antarctic environment. V. Accumulation in marine sediments. In: Hughson T, Ruckstuhl C (eds) Proc Sixth Int Symp Cold Region Development, Hobart. ISCORD, Hobart, p 136-139

Snape I, Cole C, Gore D, Riddle M, Yarnall M (1998a) A preliminary assessment of contaminants at the abandoned Wilkes Station, East Antarctica, with recommendations for establishing an environmental management strategy. Australian Antarctic Division, Kingston, Tasmania

Snape I, Riddle M, Gore D, Cole C (1998b) Interim report on the contaminated sites of the 'Old' Casey tip and abandoned Wilkes Station. Australian Antarctic Division, Kingston, Tasmania

Snape I, Riddle MJ, Stark JS, Cole CM, King CK, Duquesne S, Gore DB (2001) Management and remediation of contaminated sites at Casey Station, Antarctica. Polar Rec 37: 199-214

Snedecor GW, Cochran WG (1980) Statistical methods. Iowa State University Press, Ames

Snelgrove PV, Grassle JF, Petrecca RF (1994) Macrofaunal response to artificial enrichments and depressions in a deep-sea habitat. J Mar Res 52:345-369

Spies RB, Hardin DD, Toal JP (1988) Organic enrichment or toxicity? A comparison of the effects of kelp and crude oil in sediments on the colonization and growth of benthic infauna. J Exp Mar Biol Ecol 124:261-282

Stark JS (1998) Heavy metal pollution and macrobenthic assemblages in soft-sediments in two Sydney estuaries, Australia. J Mar Freshw Res 49:533-540

Stark JS (2000) The distribution and abundance of soft-sediment macrobenthos around Casey Station, east Antarctica. Polar Biol 23:840-850

Stark JS (2001) Human impacts and assemblages in marine soft-sediments at Casey Station, Antarctica. PhD thesis, University Of New England, Armidale, Australia

Stark JS, Riddle MJ, Simpson RD (2003a) Human impacts in soft-sediment assemblages at Casey Station, east Antarctica: spatial variation, taxonomic resolution and data transformation. Austral Ecol 28:287-304

Stark JS, Riddle MJ, Snape I, Scouller RC (2003b) Human impacts in Antarctic marine soft-sediment assemblages: correlations between multivariate biological patterns and environmental variables. Estuar Coast Shelf Sci 56: 717-734

Stark JS, Snape I, Riddle MJ (2003c) The effects of hydrocarbon and heavy metal contamination of marine sediments on recruitment of Antarctic soft-sediment assemblages: a field experimental investigation. J Exp Mar Biol Ecol 283: 21-50

Tate PM, Cathers B, Morris CE (2000) Contaminants in the Antarctic environment IV: dispersion in the marine environment. In: Hughson T, Ruckstuhl C (eds) Proc Sixth Int Symp Cold Region Development, Hobart. ISCORD, Hobart, p 132-135

Underwood AJ (1981) Techniques of analysis of variance in experimental marine biology and ecology. Oceanogr Mar 
Biol Annu Rev 19:513-605

Underwood AJ (1991) Beyond BACI: experimental designs for detecting human environmental impacts on temporal variations in natural populations. Aust J Mar Freshwat Res 42: 569-587

Underwood AJ (1992) Beyond BACI: the detection of environmental impacts on populations in the real but variable world. J Exp Mar Biol Ecol 161:145-178

Underwood AJ (1993) The mechanics of spatially replicated sampling programmes to detect environmental impacts in a variable world. Aust J Ecol 18:96-116

Underwood AJ (1994) On beyond BACI: sampling designs that might reliably detect environmental disturbances. Ecol Appl 4:3-15

Underwood AJ (1997) Experiments in ecology: their logical design and interpretation using analysis of variance. Cambridge University Press, Cambridge, UK

Underwood AJ, Denley EJ (1984) Paradigms, explanations

Editorial responsibility: John Gray (Contributing Editor), Oslo, Norway and generalizations in models for the structure of intertidal communities on rocky shores. In: Simberloff D, Abele LG, Thistle AB, Strong D (eds) Ecological communities: conceptual issues and the evidence. Princeton University Press, Princeton, NJ, p 151-180

Warwick RM, Clarke KR (1993) Increased variability as a symptom of stress in marine communities. J Exp Mar Biol Ecol 172:215-226

Watzin MC, Roscigno PR (1997) The effects of zinc contamination on the recruitment and early survival of benthic invertebrates in an estuary. Mar Pollut Bull 34:443-455

Weston DP (1990) Quantitative examination of macrobenthic community changes along an organic enrichment gradient. Mar Ecol Prog Ser 61:233-244

White MG (1984) Marine benthos. In: Laws RM (ed) Antarctic ecology, Vol 2. Academic Press, London, p 421-461

Woodin SA (1986) Settlement of infauna: larval choice? Bull Mar Sci 39:401-407

Submitted: June 13, 2003; Accepted: March 1, 2004 Proofs received from author(s): July 14, 2004 